\title{
Advances in plant growth-promoting bacterial inoculant technology: formulations and practical perspectives (1998-2013)
}

\author{
Yoav Bashan • Luz E. de-Bashan • S. R. Prabhu • \\ Juan-Pablo Hernandez
}

Received: 9 July 2013 / Accepted: 21 October 2013 / Published online: 19 November 2013

(C) Springer Science+Business Media Dordrecht 2013

\begin{abstract}
Background Inoculation of plants to enhance yield of crops and performance of other plants is a century old, proven technology for rhizobia and a newer venue for plant growth-promoting bacteria and other plant symbionts. The two main aspects dominating the success of inoculation are the effectiveness of the bacterial isolate and the proper application technology.

Scope An assessment of practical aspects of bacterial inoculants for contemporary agriculture and environmental restoration is critically evaluated from the point
\end{abstract}

Dedication This review is dedicated to the memory of the Israeli soil microbiologist Prof. Yigal Henis (1926-2010) of the faculty of Agriculture, The Hebrew University of Jerusalem in Rehovot, Israel, one of the pioneers of studies of inoculants in Israel

Responsible Editor: Philippe Hinsinger.

Electronic supplementary material The online version of this article (doi:10.1007/s11104-013-1956-x) contains supplementary material, which is available to authorized users.

Y. Bashan $(\triangle) \cdot$ L. E. de-Bashan · J.-P. Hernandez Environmental Microbiology Group, Northwestern Center for Biological Research (CIBNOR), Av. Instituto Politécnico Nacional 195, Col. Playa Palo de Santa Rita Sur, La Paz, BCS 23096, Mexico

e-mail: bashan@cals.arizona.edu

Y. Bashan • L. E. de-Bashan · J.-P. Hernandez The Bashan Foundation, 3740 NW Harrison Blvd, Corvallis, OR 97330, USA

S. R. Prabhu

TerraBioGen Technologies, 8536 Baxter Place, Burnaby, BC V5A 4T8, Canada of view of their current technological status, current applications, and future use. This is done because there are windows of opportunity for new developments in applied research using renewable, non-contaminated natural resources and new venues for research. Special emphasis is given to formulations and polymeric carriers. This review concentrates on practical aspect of inoculation technology dating from 1998 to 2013. Earlier publications are mentioned only for clarification of a specific point.

Conclusions This review discusses characteristics of a carrier for inoculants, formulations of inoculants including liquid, organic, inorganic, polymeric, and encapsulated formulations. Technical aspects include inoculation techniques (soil and seed application), mass culture production, bulk sterilization, seed coating, shelf-life, and effect of moisture. Future research venues needed are noted.

Keywords Inoculants Plant growth-promoting bacteria . PGPR $\cdot$ PGPB $\cdot$ Rhizobia

\section{Introduction}

Inoculation of plants with plant growth-promoting bacteria (PGPB) and plant symbionts to enhance performance of plants is centuries old. Yet, improvements in plant growth were not attributed to inoculation with microorganisms. Since the discovery of rhizobia in 1886 (Hellriegel 1886, cited in Date 2001) and for about 
120 years, Rhizobium inoculants have been commercially produced worldwide, mainly in developed countries (Catroux et al. 2001; Deaker et al. 2004). For the large majority of developing countries, inoculant technology, especially with PGPB, has no or little impact on productivity of family farms because inoculants are not used, are of poor quality, or are homemade (Bashan 1998). Surprisingly, and probably as a result of the potential for cheaper production of inoculants by small companies, compared to expensive chemical fertilizers and pesticides, many practical studies of numerous crops were performed in developing countries, such as the Indian subcontinent (Johri et al. 2003), Vietnam (Cong et al. 2009), and on cereals and legumes in Latin America, mainly in Argentina and Mexico (Diaz-Zorita and Fernandez-Canigia 2009; Hartmann and Bashan 2009; Fuentes-Ramirez and Caballero-Mellado 2005) and in Africa (Atieno et al. 2012; Mathu et al. 2012).

In general, shortly after suspensions of bacteria are inoculated into the soil without a proper carrier, the bacteria population declines rapidly for most species of PGPB. This phenomenon, combined with poor production of bacterial biomass, difficulty sustaining activity in the rhizosphere, and the physiological state of the bacteria at application time, can prevent the buildup of a sufficiently large PGPB population in the rhizosphere. A threshold number of cells, which differs among species, is essential to obtain the intended positive plant response, for example, $10^{6-} 10^{7}$ cells $\cdot$ plant $^{-1}$ for the PGPB Azospirillum brasilense (Bashan 1986b). The inherent heterogeneity of the soil is the key obstacle, where introduced bacteria sometimes cannot find an empty niche in the soil. These unprotected, inoculated bacteria must compete with the often better-adapted native microflora and withstand predation by soil microfauna. Consequently, a major role of formulation of inoculants is to provide a more suitable microenvironment, combined with physical protection for a prolonged period to prevent a rapid decline of introduced bacteria. Inoculants for field-scale use have to be designed to provide a dependable source of bacteria that survives in the soil and become available to crops, when needed (Bashan 1998). Many inoculants do not do this, yet this is the main purpose of inoculant formulation.

The first goal when considering inoculation of plants with PGPB (including rhizobia) is to find the best strain of bacteria or a microbial consortium for the intended effect on the target crop. The next step is to design a specific inoculant formulation for the target crop and a method of practical application, considering the limitations of the growers. A flow diagram showing the procedures for developing microbial inoculants by the industry is presented in Fig. 1. In practical terms, the chosen formulation and method of application determine the potential success of the inoculant. The scientific literature abounds with many potentially highly useful strains that did not appear on the commercial market, perhaps because of inappropriate formulation. These are lost or forgotten.

In the last decade, several reviews summarized the field of plant inoculation. Most concentrated on specific genera, such as Rhizobia (Catroux et al. 2001; Deaker et al. 2004; Herridge 2007; Stephens and Rask 2000), Azospirillum (Bashan et al. 2004; Bashan and deBashan 2010), field performance of several PGPB (Rizvi et al. 2009), availability of various PGPBs and their modes of action (Andrews et al. 2003; Lodewyckx et al. 2002; Lucy et al. 2004; Vessey 2003), reduction in the use of fertilizers by including inoculants (Adesemoye and Kloepper 2009), and potential marketing (Mathre et al. 1999; Berg 2009). Although some reviews briefly mentioned formulations and practical aspects of inoculants, none of these recent reviews concentrated on that topic; this is the niche selected for this review.

In this review, bacterial isolates refer to specific bacterial strain (PGPB or rhizobia) that can promote plant growth after inoculation. "Carrier" refers to the abiotic substrate (solid, liquid, or gel) that is used in the formulation process. "Formulation" refers to the laboratory or industrial process of unifying the carrier with the bacterial strain. "Inoculant" refers to the final product of formulation containing a carrier and bacterial agent or consortium of microorganisms. "Quality control" refers to the process of measuring defined quality parameters of the inoculant. "Quality assurance" is the overall evaluation that quality control procedures and techniques are achieving what they intend to achieve. In legumes, the quality of the inoculant is defined as the number of viable and effective cells capable of nodulating plants and fixing nitrogen of the intended strain delivered by the inoculant at point-of-sale. For PGPB, similar parameters apply, with higher emphasis on contaminant-free inoculants (Bashan 1998; Deaker et al. 2011).

The purpose of this comprehensive review are to: (1) provide state-of-the art information of scattered, hard-tofind, practical findings of the last 15 years; (2) point out present and possible future trends in inoculant technology; and (3) present possible research pathways for the 


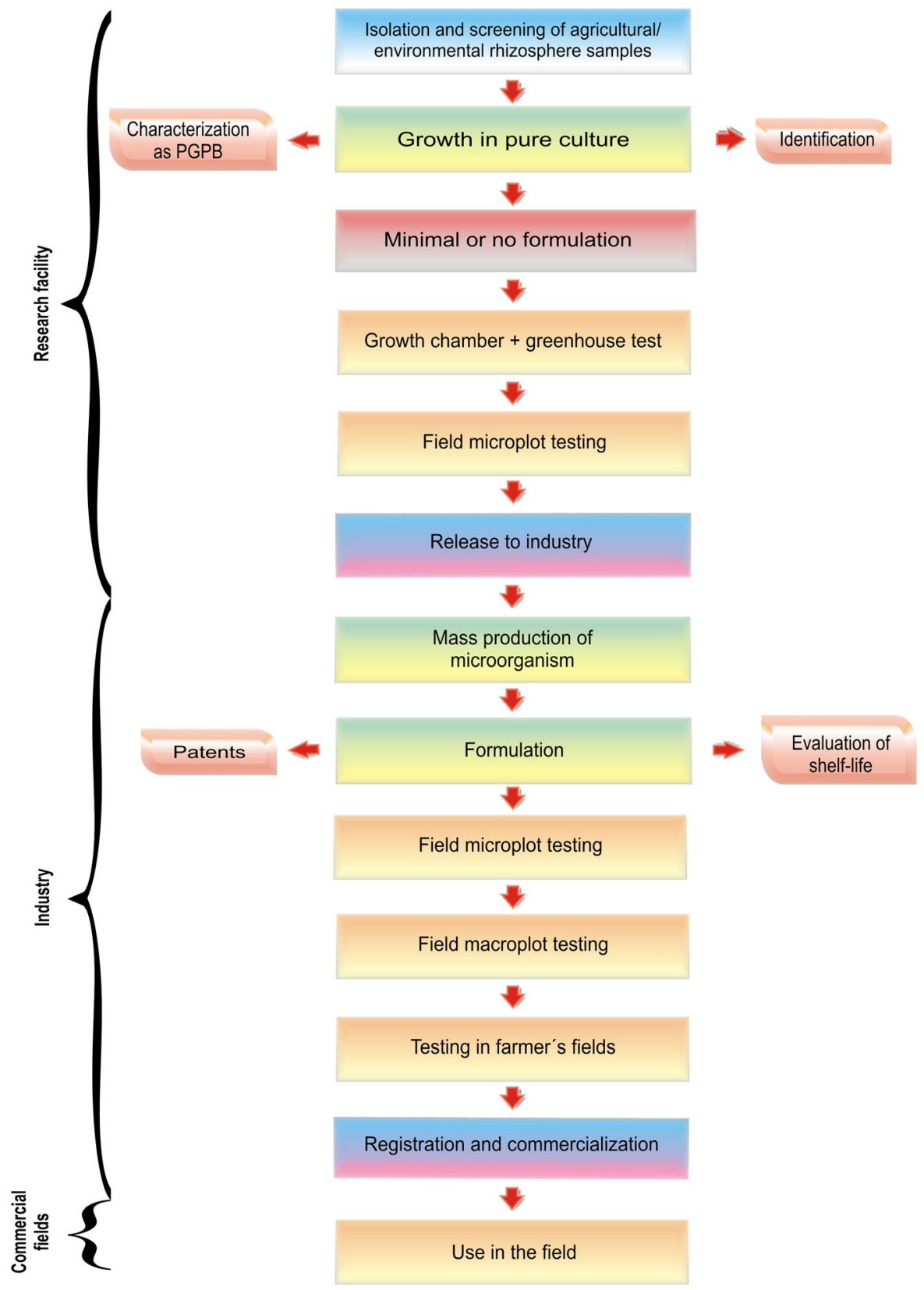

Fig. 1 Flow diagram of procedures for developing bacterial inoculants

construction of better inoculants for agriculture and environmental uses.

\section{Characteristics of a carrier for inoculants; the ideal inoculant}

To design a proper inoculant, a research project has to consider the growers' and the manufacturer' interests, which are complementary. In practice, and above all, growers always seek maximum yield. The main practical features of inoculants expected by the grower are that the inoculant has to be compatible with routine field practices, such as seed disinfection and the common use of pesticides. Secondarily, important features of inoculants are: (1) ease of use, (2) compatibility with the seeding equipment at the time of seeding, (3) tolerance of abuse during storage, (4) ability to work under 
different field conditions and types of soil, and, (5) ability to help prolong survival of the inoculated bacteria for the time needed by the plant. The extra requirements of manufacturers are: (6) shelf life that lasts more than one season, (7) reproducible results in the field, and (8) human, animal, and plant safety by eliminating the use of hazardous materials.

All this should occur in a marketplace where there is no international standard for quality of inoculants. In practice, inoculant quality can be under governmental regulations as happens in The Netherlands, Thailand, Russia, Canada, France, and Australia (voluntarily) or leave product quality and rate of application to the discretion of the manufacturer, as happens in the United States, Mexico, Argentina, and the United Kingdom. This ambiguity in the 1980-1990s led to inadequate performance of commercial PGPB inoculants and subsequent abandonment of their use on a global scale (Catroux et al. 2001; Stephens and Rask 2000). These inoculants made a strong comeback in the last decade, concentrated in Latin America (FuentesRamirez and Caballero-Mellado 2005; Diaz-Zorita and Fernandez-Canigia 2009; Hartmann and Bashan 2009) and southeast Asia, mainly in India (Bhattacharya and Mishra 1994; Nguyen et al. 2003; Selvamukilan et al. 2006; Reddy and Saravanan 2013).

The three fundamental and essential characteristics for all inoculants are to: (1) support the growth of the intended microorganisms, (2) support the necessary number of viable microbial cells in good physiological condition for an acceptable period of time (Stephens and Rask 2000), and (3) deliver enough microorganisms at the time of inoculation to reach a threshold number of bacteria that is usually required to obtain a plant response, i.e., the inoculant must contain enough viable bacteria after the formulation process (Date 2001).

Factors that may influence efficacy of inoculants are those that provide better survival of the inoculant on the seed. Those include: (1) growth phase (logarithmic or stationary) at the time of mixing bacterial cultures with a carrier because these influence incorporation into the inoculant of either very active cells, spores, cysts, or flocculated cells of various species of PGPB (for review, see Bashan 1998), (2) rate of drying and rehydration, (3) appropriate carrier material characteristics, and (4) inoculation technology (Date 2001). In practice, the formulated carrier (inoculant) is the sole delivery vehicle of live microorganisms from the factory to the field. The carrier is the major portion (by volume or weight) of the inoculant. Inoculant carriers can be divided into five basic categories: (1) Soils: peat, coal, clays, and inorganic soil, (2) Waste plant materials of diverse industrial and agriculture origins (examples listed in Table 1), (3) Inert materials: polymers, treated rock fragments, such as vermiculite and perlite, (4) Plain lyophilized microbial cultures and oil-dried bacteria that can later be incorporated into a solid carrier or used as they are, and (5) Liquid inoculants, where some chemical was added to the liquid medium containing the PGPB to improve stickiness, stabilization, surfactant, function, and dispersal (for review of earlier studies: Bashan 1998) (Fig. 2).

To produce a microbial inoculant, the microorganism of choice is commonly formulated into either a sterile or non-sterile carrier. A sterile carrier has significant advantages of delivering the right microorganism at the precise concentration, avoiding the often unpredictable potential for the indigenous organisms to suppress cell numbers. Therefore, there is more control over inoculum potential; however, the sterilization process renders the inoculant far less cost effective, especially in developing countries (discussed later). Yet, sterile and more pricy inoculants have been successfully marketed in the USA, Australia, Canada, Mexico, and Argentina.

Formulation is the crucial issue for commercial inoculants. This industrial process can determine the commercial success or failure of a biological agent that has outstanding performance in a research facility. Formulation is the industrial "secret art" of converting a promising laboratory-proven microorganism, carefully-cultivated by skilled specialists in carefully designed and supervised experiments into a commercial product used by common growers under uncontrolled field conditions. Growers are seeking repeated positive results, easy handling, and reasonably priced. Growers have a limited time for complicated or laborious maintenance.

Because chemical formulations of agroproducts set high standards for long shelf life, ease of use, and resistance to abuse by farmers, microbial inoculant formulations are expected at least to match them. Additionally, inoculants must overcome two major problems inherent to living microorganisms: (1) loss of viability during short storage in the grower's warehouse, and (2) long shelf life and stability of the product over a range of -5 to $30^{\circ} \mathrm{C}$, within growers' storage conditions. 
Table 1 A sample of formulations used for producing inoculants of plant growth-promoting bacteria for plants from 1998 to 2014

\begin{tabular}{llll}
\hline Formulation & $\begin{array}{l}\text { Additives or } \\
\text { treatment }\end{array}$ & Microorganisms used & $\begin{array}{l}\text { Plant species, or } \\
\text { substrate }\end{array}$
\end{tabular} Reference

No formulation (culture None
media or water).
Imbibing of seeds or
irrigating substrate
with inoculum.

\author{
Carboxymethyl \\ cellulose \\ Carboxymethyl \\ cellulose \\ Carboxymethyl \\ cellulose
}

Glycerol, PVP, trehalose, FeEDTA, PVP; FeEDTA

Unknown (commercial)

Sucrose

Gum Arabic

Glycerol

Organic inoculants Peat
Azospirillum brasilense; A. zeae; Apricot; alfalfa; A. rugosum; Azotobacter sp; Beijerinckia sp.; Bacillus sp.; B. mycoides; B. pumilus; $B$. polymyxa, Burkholderia pyrrocinia; B. phytofirmans; Enterobacter cloacae; Lysobacter gummosus, Mycobacterium phlei; Methylobacterium oryzae; Paenibacillus polymyxa; Pantoea sp.; Pseudomonas fluorescens; P. alcaligenes; $P$. chlororaphis; P. aureofaciens; P. putida; Pichia guilermondii; PSB; Serratia plymuthica, Sinorhizobium meliloti; Stenotrophomonas maltophilia; Sphingobacterium canadense barley; Brassica chinensis; cacti; Calliandra calothyrsus; chickpea; Chinese cabbage; common poppy; cucumber; Italian ryegrass; lemongrass; lentil; linseed; maize; mesquite; mulberry; pepper; rapeseed; rice; rye; strawberry; styrian oil pumpkins; sugar beet; sunflower; tomato; turfgrass; walnut; wheat;
Afzal et al. 2012; Alström 2001; Amein and Weber 2002; Anith et al. 2004; Bacilio et al. 2003, 2004; Bashan et al. 2006; Boruah and Kumar 2002; Cakmakci et al. 2001, 2006; Carrillo-Garcia et al. 2000; Dominguez-Nuñez et al. 2012; Egamberdiyeva 2007; Esitken et al. 2003; Fürnkranz et al. 2012; Guetsky et al. 2002a, b; Guiñazú et al. 2010; Hossain and Mårtensson 2008; Jetiyanon et al. 2003; Khan et al. 2003; Kurek and Jaroszuk-Ściseł 2002; Landa et al. 2001; Lopez et al. 2013; Madhaiyan et al. 2010; Mehnaz et al. 2010; Odee et al. 2002; Ozturk et al. 2003; Puente et al. 2004a, b, 2009a, b; Rajapaksha et al. 2011; Singh et al. 2011; Sigler et al. 2001; Sudhakar et al. 2000; Yan et al. 2003; Yu et al. 2011; Zafar et al. 2012

Dal Bello et al. 2002

Viji et al. 2003

Pseudomonas aeruginosa ryegrass

Acinetobacter calcoaceticus, Jatropha curcas

Jha and Saraf 2012 Bacillus licheniformis, Brevibacillus brevis, Micrococcus sp., Bradyrhizobium japonicum

Soybean

Singleton et al. 2002

Several rhizobia; Bradyrhizobium japonicum; Bacillus megaterium

Bradyrhizobium japonicum

Phosphate solubilizing bacteria; Bacillus subtilis; $B$. amyloliquefaciens; Pseudomonas spp.

Bradyrhizobium sp.; Rhodobacter capsulatus; Rhizobium sp.

\section{Soybean}

Albareda et al. 2008

Soybean

Peanut, rice

(n)

Acacia mangium, Greengram, Leucaena leucocephala; Rice

Tomato

Pseudomonas fluorescens

Azospirillum brasilense; $A$.
Chickpea; faba beans; maize; lipoferum; (PGPR, auxin
None or with undisclosed 
Table 1 (continued)

\begin{tabular}{|c|c|c|c|c|}
\hline Formulation & $\begin{array}{l}\text { Additives or } \\
\text { treatment }\end{array}$ & Microorganisms used & $\begin{array}{l}\text { Plant species, or } \\
\text { substrate }\end{array}$ & Reference \\
\hline & $\begin{array}{l}\text { additives. } \\
\text { Applications as: } \\
\text { seed coating } \\
\text { and pellets }\end{array}$ & $\begin{array}{l}\text { producers); Bradyrhizobium } \\
\text { japonicum; Rhizobium sp.; } \\
\text { Rhizobium leguminosarum } \\
\text { bv. viceae }\end{array}$ & $\begin{array}{l}\text { pea; soybean; } \\
\text { wheat, }\end{array}$ & $\begin{array}{l}\text { Hynes et al. 2001; Khalid et al. } \\
\text { 2004; Revellin et al. } 2000\end{array}$ \\
\hline Peat & Vermiculite & $\begin{array}{l}\text { PGPB (Bacillus spp); } \\
\text { Rhizobia (non specify) }\end{array}$ & $\begin{array}{l}\text { Muskmelon and } \\
\text { watermelon; } \\
\text { Calliandra } \\
\text { calothyrsus }\end{array}$ & $\begin{array}{l}\text { Kokalis-Burelle et al. 2003; Odee } \\
\quad \text { et al. } 2002\end{array}$ \\
\hline Peat & $\begin{array}{l}\text { Chitin, heat-killed } \\
\text { Aspergillus niger } \\
\text { mycelium, spent } \\
\text { compost from } \\
\text { champignon }\end{array}$ & $\begin{array}{l}\text { Bacillus subtilis Klebsiella } \\
\text { pneumoniae }\end{array}$ & $\begin{array}{l}\text { Groundnuts; } \\
\text { pigeon pea, }\end{array}$ & Manjula and Podile 2001 \\
\hline Peat & $\begin{array}{l}\text { Pyrophyllite } \\
\text { (hydrous } \\
\text { aluminum } \\
\text { silicate) }\end{array}$ & $\begin{array}{l}\text { Trichoderma virens and } \\
\text { Burkholderia cepacia }\end{array}$ & Bell pepper & Meyer et al. 2000, 2001 \\
\hline Peat & charcoal, adhesive & $\begin{array}{l}\text { Diazotrophs (Klebsiella } \\
\text { pneumoniae Pantoea } \\
\text { agglomerans } \\
\text { Gluconacetobacter } \\
\text { diazotrophicus } \\
\text { Herbaspirillum seropedicae) }\end{array}$ & Maize & Riggs et al. 2001 \\
\hline Peat & Sugar & Azospirillum brasilense & wheat & Piccinin et al. 2013 \\
\hline Peat & Arabic gum & $\begin{array}{l}\text { Several Rhizobium and } \\
\text { Bradyrhizobium }\end{array}$ & $\begin{array}{l}\text { Bean; Lupinus, } \\
\text { Hedysarum; } \\
\text { soybean }\end{array}$ & $\begin{array}{l}\text { Albareda et al. 2009; Temprano } \\
\text { et al. } 2002\end{array}$ \\
\hline Coir dust/coco peat & None & Azorhizobium caulinodans & rice & Van Nieuwenhove et al. 2000 \\
\hline $\begin{array}{l}\text { Vermicompost/ } \\
\text { earthworm } \\
\text { compost }\end{array}$ & lignite & $\begin{array}{l}\text { Azotobacter chroococcum, } \\
\text { Bacillus megaterium } \\
\text { and Rhizobium leguminosarum }\end{array}$ & Not tested & Raja Sekar and Karmegam 2010 \\
\hline Charcoal & $\begin{array}{l}\text { CMC and Gum } \\
\text { acacia; }\end{array}$ & $\begin{array}{l}\text { Pseudomonas jessenii; } P \text {. } \\
\text { Synxantha and arbuscular } \\
\quad \text { mycorrhizal fungi }\end{array}$ & $\begin{array}{l}\text { black gram; rice, } \\
\text { wheat }\end{array}$ & Mäder et al. 2011 \\
\hline Residues of Azolla & $\mathrm{FeSO}_{4}$ & Azolla & Cucumber & Plessner et al. 1998 \\
\hline Sawdust & $\begin{array}{l}\text { Composted by } \\
\text { inoculation with } \\
\text { Cephalosporium } \\
\text { sp. and } \\
\text { Azospirillum } \\
\text { brasilense }\end{array}$ & $\begin{array}{l}\text { Bradyrhizobium japonicum } B . \\
\quad \text { arachis Rhizobium meliloti } R . \\
\quad \text { lotus, Azospirillum brasilense }\end{array}$ & $\begin{array}{l}\text { Groundnuts, lucerne } \\
\text { and a grass } \\
\text { mixture of bird's } \\
\text { foot trefoil and } \\
\text { ryegrass; } \\
\text { Soybean }\end{array}$ & Kostov and Lynch 1998 \\
\hline Sawdust & None & $\begin{array}{l}\text { Rhizobium leguminosarum and } \\
\text { Pseudomonas fluorescens }\end{array}$ & Trifolium repense & Arora et al. 2008 \\
\hline Lignin & Corn straw & Azotobacter vinelandii & Not tested & Zhang et al. 2004 \\
\hline $\begin{array}{l}\text { Soybean or } \\
\text { wheat bran }\end{array}$ & None & $\begin{array}{l}\text { Yeasts, Chitinolytic bacterium } \\
\text { and Streptomyces griseoluteus }\end{array}$ & Bean; Sugar beet & $\begin{array}{l}\text { El-Tarabily 2004; El-Tarabily } \\
\text { et al. 2000; Nassar et al. } 2003\end{array}$ \\
\hline Wheat or oat bran & $\mathrm{CMC}$ & $\begin{array}{l}\text { Bacillus subtilis; } \\
\quad \text { Pseudomonas putida }\end{array}$ & Cucumber; lettuce & Amer and Utkhede 2000 \\
\hline $\begin{array}{l}\text { Fibers from brewer's } \\
\text { spent barley grain }\end{array}$ & None & Streptomyces grisoviridis & Not tested & Tuomi et al. 2001 \\
\hline \multirow[t]{2}{*}{$\begin{array}{l}\text { Grape bagasse, } \\
\text { cork compost }\end{array}$} & $\begin{array}{l}\text { Gum Arabic, } \\
\text { CMC }\end{array}$ & $\begin{array}{l}\text { Several rhizobia; } \\
\text { Bradyrhizobium japonicum; } \\
\text { Bacillus megaterium }\end{array}$ & Soybean & Albareda et al. 2008 \\
\hline & None & & Banana & Rivera-Cruz et al. 2008 \\
\hline
\end{tabular}


Table 1 (continued)

Plant species, or Reference

substrate

\begin{tabular}{|c|c|c|}
\hline Formulation & $\begin{array}{l}\text { Additives or } \\
\text { treatment }\end{array}$ & Microorganisms used \\
\hline $\begin{array}{l}\text { Poultry manure and } \\
\text { banana waste }\end{array}$ & & $\begin{array}{l}\text { Azospirillum sp., Azotobacter } \\
s p . \text { and undefined PSB }\end{array}$ \\
\hline Wastewater sludge & $\begin{array}{l}\text { Acid, alkaline } \\
\text { and oxidative } \\
\text { pre-treatments }\end{array}$ & $\begin{array}{l}\text { Sinorhizobium meliloti, } \\
\text { Rhizobium leguminosarum } \\
\text { bv viciae, Bradyrhizobium } \\
\text { japonicum and B. elkanii }\end{array}$ \\
\hline \multicolumn{3}{|l|}{ Inorganic inoculants } \\
\hline Clay Soil & Elemental S & $\begin{array}{l}\text { Co-inoculation Rhizobium } \\
\text { Sp. and Thiobacillus sp. }\end{array}$ \\
\hline Clay soil & Rice husks, sugar & Multi strain PGPB \\
\hline Loess soil & None & PSB-Rhizobium sp. \\
\hline $\begin{array}{l}\text { Clay minerals, } \\
\text { perlite }\end{array}$ & Gum Arabic, CMC & $\begin{array}{l}\text { Several rhizobia; } \\
\text { Bradyrhizobium japonicum; } \\
\text { Bacillus megaterium }\end{array}$ \\
\hline Kaolin & $\mathrm{CMC}$ & $\begin{array}{l}\text { Bacillus subtilis; } \\
\quad \text { Pseudomonas putida }\end{array}$ \\
\hline Local soils & None & $\begin{array}{l}\text { Undefined cyanobacteria; } \\
\text { Rhizobia (non define) }\end{array}$ \\
\hline Turf & None & Azospirillum brasilense \\
\hline $\begin{array}{l}\text { Torrefied grass } \\
\text { fibers }\end{array}$ & None & $\begin{array}{l}\text { Coniochaeta Ligniaria }+ \\
7 \text { PBPB strains }\end{array}$ \\
\hline $\begin{array}{l}\text { Activated carbon } \\
\text { filters }\end{array}$ & None & Rhodococcus rhodochrous \\
\hline Talc & None & Pseudomonas fluorescens \\
\hline
\end{tabular}

Not tested

Ben Rebah et al. 2002a, b

CMC Bacillus subtilis; Pseudomonas putida

Talc

Clay pellets

None

Perlite

Gum Arabic

A. brasilense; Pantoea dispersa

Rhizobium and Bradyrhizobium

Vermuculite
EB $^{\mathrm{TM}}$ (mainly clay
and wood
particles)

Polymeric inoculants

$\begin{array}{ll}\text { Alginate } & \text { None } \\ \text { Alginate } & \text { none } \\ \text { Alginate } & \text { None }\end{array}$

$\begin{array}{ll}\text { Alginate } & \text { None } \\ \text { Alginate } & \text { None }\end{array}$

CMC

Vermiculite, sucrose asparagine broth

Bacillus subtilis; Pseudomonas putida Pseudomonas fluorescens None none None

None

None
Azospirillum brasilense

Azospirillum brasilense

Azospirillum brasilense; A. lipoferum; Pseudomonas fluroescens; Bacillus megaterium Agaricus bisporus (champignon);

Chlorella vulgaris, $C$. sorokiniana together with Azospirillum brasilense,
Groundnut

Rice

None

Soybean

Cucumber; lettuce,

Calliandra calothyrsus; rice

Several grasses

Tomato

Contaminated water Jones et al. 1998 with atrazine

blue pine; chillies, mango, mungbean; rice, sugarcane, tea,

Anandham et al. 2007

Nguyen et al. 2003

Li et al. 2011

Albareda et al. 2008

Amer and Utkhede 2000

Hashem 2001; Odee et al. 2002

Garcia and Sarmiento 2000

Trifonova et al. 2009

Ahangar et al. 2012; Bharathi et al. 2004; Radjacommare et al. 2002; Saravanakumar et al. 2007a, b, 2009;

Viswanathan and Samiyappan 2001; Vivekananthan et al. 2004

Cucumber; lettuce, Amer and Utkhede 2000

Cistus albidus

Schoebitz et al. 2014

Bean; Lupinus, Hedysarum; soybean

Cucumber; lettuce

Amer and Utkhede 2000

Sugarbeet

Moënne-Loccoz et al. 1999

Tomato,

Bashan et al. 2002; Yabur et al. 2007

Several desert trees

Wheat

Bashan et al. 2009a, b, 2012

Bashan et al. 2006; Bacilio et al. 2004; Bashan and Gonzalez 1999; El-Komy 2005

Friel and McLoughlin 1999

Tertiary wastewater treatment
de-Bashan et al. 2002a, b; deBashan et al. 2004; de-Bashan et al. 2005, 2008a, b, c; 
Table 1 (continued)

\begin{tabular}{|c|c|c|c|c|}
\hline Formulation & $\begin{array}{l}\text { Additives or } \\
\text { treatment }\end{array}$ & Microorganisms used & $\begin{array}{l}\text { Plant species, or } \\
\text { substrate }\end{array}$ & Reference \\
\hline & & $\begin{array}{l}\text { Bacillus pumilus or } \\
\text { Phyllobacterium } \\
\text { myrsinacearum }\end{array}$ & & $\begin{array}{l}\text { de-Bashan and Bashan 2004, } \\
\text { 2008; Gonzalez and Bashan } \\
\text { 2000; Gonzalez-Bashan et al. } \\
\text { 2000; Hernandez et al. 2009; } \\
\text { Lebsky et al. 2001; Perez- } \\
\text { Garcia et al. } 2010\end{array}$ \\
\hline Alginate & None & Pseudomonas fluorescens & Sugar beet & Russo et al. 2001 \\
\hline Alginate & None & $\begin{array}{l}\text { Pseudomonas striata; Bacillus } \\
\quad \text { polymyxa }(P S B)\end{array}$ & None & Viveganandan and Jauhri 2000 \\
\hline Alginate & None & $\begin{array}{c}\text { Glomus deserticola }(\text { AM } \\
\text { mycorrhizae); Yarowia } \\
\text { lipolytica }(P S \text {-yeast })\end{array}$ & Tomato & Vassilev et al. 2001 \\
\hline Alginate & None & Pseudomonas putida & Corn; velvetleaf & Gurley and Zdor 2005 \\
\hline Alginate & None & Rhizobium spp. & $\begin{array}{l}\text { Leucaena } \\
\quad \text { leucocephala }\end{array}$ & Forestier et al. 2001 \\
\hline Alginate & Kaolin, starch, talc & Streptomycetes sp. & tomato & Sabaratnam and Traquair 2002 \\
\hline Alginate & Starch & $\begin{array}{l}\text { Raoultella terrigena, } \\
\text { Azospirillum brasilense }\end{array}$ & None & Schoebitz et al. 2012 \\
\hline Alginate & Humic acid & $\begin{array}{l}\text { Pseudomonas putida and } \\
\text { Bacillus subtilis }\end{array}$ & Lettuce & Rekha et al. 2007 \\
\hline Alginate & Peanut oil & Beauveria bassiana & Red fire ants & Bextine and Thorvilson 2002 \\
\hline Alginate & Skim milk & $\begin{array}{l}\text { Bacillus subtilis and } \\
\text { Pseudomonas corrugata }\end{array}$ & Maize & Trivedi et al. 2005 \\
\hline Alginate & Glycerol, chitin & Pantoae agglomerance & None & Zohar-Perez et al. 2002 \\
\hline Alginate & Chitin, bran & None & $\begin{array}{l}\text { Cabbage, basil, } \\
\text { radish; wheat, }\end{array}$ & Sarrocco et al. 2004 \\
\hline Chitosan & None & Several PGPB & Tomato & Murphy et al. 2003 \\
\hline CMC/corn starch & $\mathrm{MgO}$ & $\begin{array}{l}\text { Rhizobia; Gluconacetobacter } \\
\text { diazotrophicus, } \\
\text { Herbaspirillum seropedicae, } \\
\text { H. rubrisubalbicans, } \\
\text { Azospirillum amazonense } \\
\text { and Burkholderia tropica }\end{array}$ & Cowpea, sugarcane & $\begin{array}{l}\text { Júnior et al. 2009; da Silva et al. } \\
2012\end{array}$ \\
\hline $\begin{array}{l}\text { Ethylcellulose; } \\
\text { modified starch }\end{array}$ & Silica & Pseudomonas fluorescens & None & Amiet-Charpentier et al. 1998 \\
\hline
\end{tabular}

For earlier studies see: Bashan (1998). PSB phosphate-solubilizing bacteria; PVP polyvinylpyrrolidone; CMC Carboxymethyl cellulose

Regardless of the specific formulation, the nature of the final inoculant can be of four types: liquid, slurry, granular, or powder (Bashan 1998; Catroux et al. 2001). The raw material of the carrier and the type of formulation vary greatly. The raw materials of most commercial inoculants are cheap and naturally abundant. Apart from the most common material, peat, other materials were proposed. This list includes bagasse, animal manure, Lucerne powder, coir dust (coco peat) compost, earthworm composts, perlite, rock phosphate, charcoal, and a range of coals, lignite, talc, and inorganic soil fractions, mainly clays (Stephens and Rask 2000 and Table 1).
The five main desirable general characteristics for a good formulation are (Bashan 1998):

(1) Chemical and physical characteristics. The carrier of a contaminant-free inoculant should be nearly sterile or cheaply sterilized, as chemically and physically uniform as possible, of consistent batch quality, high water-holding capacity (for wet carriers), and suitable for as many bacterial species and strains of PGPB as possible. Consistency of raw material is an absolute requirement for all carriers. This happens because the carrier is a major 


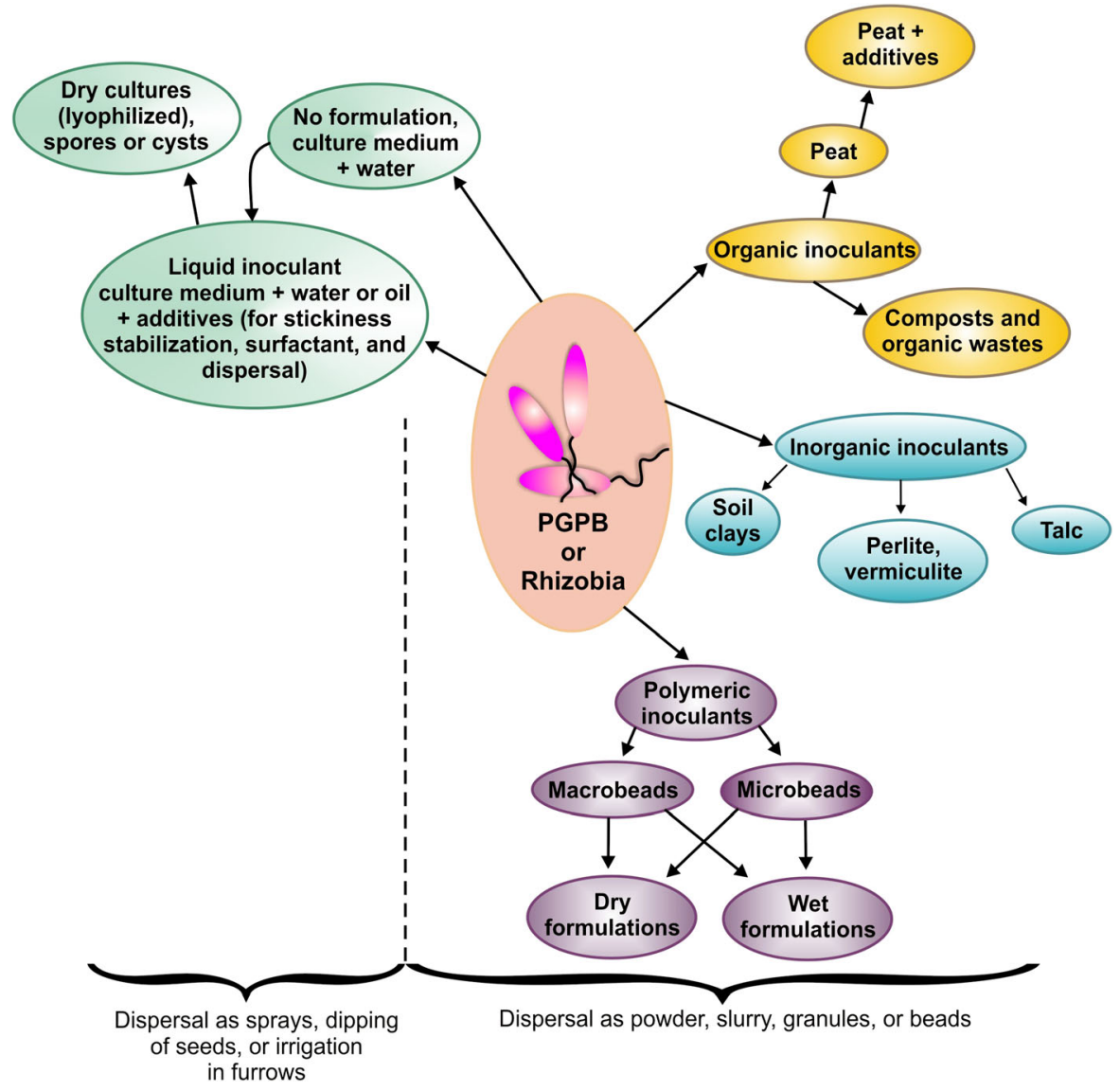

Fig. 2 Formulations of inoculants for agricultural and environmental uses

ingredient of the inoculant production. If varied, established quality control process of such inoculants cannot be adjusted for every batch of raw material during industrial inoculant production (Stephens and Rask 2000).

(2) Manufacturing qualities. Inoculants must be easily manufactured and mixed by the microbial fermentation industry. It should allow addition of nutrients, have an easily adjustable $\mathrm{pH}$, and be made of a reasonably low-priced raw material in adequate supply and availability (Catroux et al. 2001).

(3) Farm-handling qualities. Good inoculants allow for ease of handling (a major concern for the grower), provide rapid and controlled release of bacteria into the soil, and can be applied with standard seeding machinery. This is very important because it is rare that farm practices change to accommodate a technology that delivers a high quality inoculant with specialized machinery, especially in conservative farming communities (Date 2001).
(4) Environment-friendly. In accordance with contemporary environmental concerns over applications of substances that change soil characteristics, the inoculant should be nontoxic, biodegradable, leave no carbon footprint, and be nonpolluting. Application should minimize environmental risks, such as the dispersal of PGPB cells to the atmosphere or ground water.

(5) Long storage quality. The inoculant should have sufficient shelf life. One or two years at room temperature are often necessary for successful integration into the agricultural distribution system in developed countries (Catroux et al. 2001; Deaker et al. 2004).

Obviously, no single inoculant can have all these capacities at top-end quality. However, a good inoculant should have as many as possible of these desired features at reasonable quality. Synthesizing "super-inoculants" or finding a polymer used in more expensive 
industries, such as pharmaceuticals, nanotechnology, or cosmetics to accommodate all the desired features is theoretically possible and was proposed (John et al. 2011; Schoebitz et al. 2013), so far in small quantities and with no commercial products. As far as we know, no effort to synthesize a carrier with predefined superior characteristics for agricultural and environmental purposes has been reported, presumably because of the high cost.

\section{Inoculant formulations}

The performance of an inoculant is often the most common barrier for commercialization of inoculants. A microbial strain may function optimally under the care of skillful personnel and precise laboratory conditions in the research facility; yet, formulating this microorganism into an affordable product used by microbiologicallyunskilled farmers, where similar results under field condition are expected, is a difficult task (Stephens and Rask 2000). Any formulation must be stable during production, distribution, storage, and transportation to the farmer, particularly when the main ingredient is alive and susceptible to changes, compared to farm chemicals. It is paramount to get an inoculant to perform well in the type of soil where it is applied. The literature describes many forms of tested inoculants (see below and in Table 1), but commercial inoculants come in only a very few variations.

"Primitive" inoculants - culture media with no additional formulation

Surprisingly, the oldest method of inoculation of seeds and plants with bacterial culture suspension, as has been done since the pioneering times of plant inoculation decades ago, still prevails today. It is practiced mostly at research facilities. It is a very common practice, especially among highly trained researchers because it is the least laborious.

Numerous studies have shown that under careful supervision, and probably not applicable for commercial growers, good positive results of inoculation can be achieved, using the PGPB without any formulation. In the past decade, several cases, out of many, are presented in Table 1.

Obviously, despite the large number of publications demonstrating repeated success of researchers, "no formulation" inoculants are definitely not a practical inoculation technology for growers. This is mainly because the level of expertise needed for proper delivery of the bacteria, under optimal conditions, is many times beyond the skills and the available time of the growers. It is also impractical for large-scale application; the large volume of liquids involved, incubation, and refrigeration facilities needed to maintain culture medium that have no formulation make it unlikely to meet economic and commercial needs. It will serve mainly in the domain of bench and greenhouse initial experimentation in research facilities.

\section{Liquid inoculants}

Liquid inoculants are an upgraded derivative of "noformulation" inoculants to address some of the limitations listed above. Essentially, they are microbial cultures or suspensions amended with substances that may improve stickiness, stabilization, and surfactant and dispersal abilities (Singleton et al. 2002). The main advantage of these inoculants over solid inoculants is that they are easy to handle. Unlike solid carrier-based inoculants, liquid formulations allow the manufacturer to include sufficient amounts of nutrients, cell protectants, and inducers responsible for cell/spore/cyst formation to improve performance. While the shelf life of common solid carrier-based inoculants is $\sim 6$ months (or in the best of cases, 12-18 months in Australia), another advantage of a liquid formulation is that its shelf life could be as high as 2 years (see below). They have a few major disadvantages: (1) Limited shelf life in some cases (but not for all), (2) cool or cold conditions are required for long-term storage, and (3) increased costs, a fact that limits their use to developed countries and precludes use in most developing countries (Stephens and Rask 2000). They gained popularity in developed countries for legume inoculation because of high cell counts. Liquid inoculants containing concentrations of $2 \times 10^{9}$ cells per $\mathrm{mL}$ are now common, allowing for lower application rates and increased efficiency in using inoculants (Schulz and Thelen 2008). Further, it is claimed that these inoculants have no contamination and have longer shelf life for some formulations, greater protection against environmental stresses, and increased field efficacy, compared to peat-based inoculants (Singleton et al. 2002). They are compatible with machinery on large farms, such as air seeders and seed augers. Finally, they are favorable for small scale 
inoculant manufacturers in the tropics that lack the capacity to handle peat as a carrier.

These inoculants use broth cultures or liquid suspensions mainly in water, but also in mineral or organic oils. Easier handling implies that the seeds are dipped into the inoculant before sowing or, alternatively, a sprayer evenly sprays the liquid inoculant on the surface of the seeds. After the drying process (not always done), the seeds are sown. This method ensures even coverage of the seeds without interference with the seed monitoring system of the planters or inoculum loss when dried. Although many commercial products of that type are sold in the marketplace, popular in the USA, Canada, Argentina, and Brazil, mainly for soybeans, but also for lentils, peas, and peanuts, the peer-reviewed information on that topic, apart from commercial brochures, is limited and the additives on the label are proprietary information (see below).

A common additive is sucrose, which improves survival, mostly of rhizobia, but also for phosphatesolubilizing bacteria (PSB), such as Pantoea sp. This improved performance of PSB for peanuts (Taurian et al. 2010). Addition of glycerol to the culture medium preserved the viability of Pseudomonas fluorescens cells in liquid formulation for storage lasting 6 months (Taurian et al. 2010). This last finding matches the work of Singleton et al. (2002), who developed a liquid formula for Rhizobium by incorporating additives to the media for improved growth performances. Glycerol as an amendment is used because it holds a considerable amount of water and protects cells from desiccation by slowing the drying rate (Manikandan et al. 2010). Yet, most additives are polymeric in nature, with high molecular weight. These include carboxymethyl cellulose (CMC), gum arabic, and polyvinylpyrrolidone (PVP).

$\mathrm{CMC}$ is a non-ionic water soluble cellulose and is a common additive because it is readily available, has a relatively consistent batch quality as a result of being a semi-synthetic polymer, and it is relative cheap because it is used in low concentration (1/5; w/v). An example includes moistened wheat seeds that are coated with a suspension of bacterial antagonists against the fungal pathogen Fusarium graminearum or with conidial suspension of the fungal antagonist Trichoderma spp. that were previously mixed with a $1 \% \mathrm{CMC}$ solution. After curing for $20 \mathrm{~min}$, the seeds were dried for $3 \mathrm{~h}$ under a stream of sterile air. Out of 52 bacterial strains and six strains of Trichoderma spp., only one bacterial strain, Stenotrophomonas maltophilia provided reasonably good protection against the pathogen for eight different wheat cultivars (Dal Bello et al. 2002). Another biocontrol agent, $P$. aeruginosa, was cultivated in liquid medium supplemented with $0.1 \% \mathrm{CMC}$, where seeds of perennial ryegrass were soaked in the solution with $P$. aeruginosa and then dried or the solution was sprayed directly onto the leaves in the field for successful suppression of gray leaf spot (Viji et al. 2003), Similar procedures were used for preparing inoculants containing Brevibacillus brevis, Bacillus licheniformis, Micrococcus sp., and Acinetobacter calcoaceticus for inoculation of Jatropha curcas and consequently improved growth (Jha and Saraf 2012).

Gum arabic is a complex carbohydrate extracted from acacia and a commonly used adhesive for rhizobia (Deaker et al. 2011). It protects the bacteria against desiccation and improves survival. The nickel- and zinc-tolerant PGPB Bradyrhizobium sp., isolated from nodules of green gram promoted growth of this plant in nickel- and zinc-contaminated soils when inoculated with gum arabic in a liquid culture as an adhesive (Wani et al. 2007). This was also done with the inoculant Rhodobacter capsulatus to improve growth of rice (Gamal-Eldin and Elbanna 2011). Its variable quality, availability, cost, and the need for high concentration of gum arabic in the inoculant (up to $40 \% \mathrm{w} / \mathrm{v}$ ) limits its use (Deaker et al. 2004).

PVP is a synthetic vinyl polymer that aids survival of Bradyrhizobium japonicum (Singleton et al. 2002). Similar to gum arabic, PVP provides some protection from desiccation and additional protection from inhibitory seed coat exudates that are detrimental to inoculated rhizobia. Several variation of PVP are patented as seed coating (patent literature).

In summary, liquid inoculants have a share of the inoculant market. Because their advantages and disadvantages are well recognized, tailor-made inoculants for specific crop-bacteria combinations is their main niche in the market. The formulation needs to respond to a specific need. A general formulation to fit all PGPBrhizobia is unlikely. These are also the type of proprietary inoculants that the industry favors.

Inoculants using organic carriers

Without any doubt, peat is the carrier of choice for rhizobia in North and South America, Europe, and Australia, and the main ingredient of inoculants that are sold in large volumes. It fits most other PGPB. Yet, 
peat is rarely available in some countries. All other carriers proposed for PGPB-rhizobia are compared with the standard peat carrier. Its performance and drawbacks were intensively and continuously reviewed, as well as details of production of several variants. Currently, technical details of production of the basic peat-based inoculant such as grain size, $\mathrm{pH}$, optimal moisture, several amendments, quality of inoculants, quality control standards, and occupational health and safety are common knowledge (Catroux et al. 2001; Date 2001; Deaker et al. 2004, 2011; Stephens and Rask 2000; Xavier et al. 2004). Therefore, this review will not re-evaluate peat in detail and will only highlight new developments in peat-based inoculants in recent years.

The physical state of the formulation of peat (solid [powder], pellet, or liquid [slurry]) can make a difference in the success of inoculation. In peas inoculated by rhizobia in a temperate zone, population dynamics of Rhizobium leguminosarum bv. viceae in the rhizosphere exhibited the same pattern among solid formulations: an initial decline lasting 2-5 days, followed by an increase that lasted for over 2 months. In contrast, soil populations of this strain originating in liquid formulations declined to nearly zero when soil moisture was excessive in spring because of high rainfall (Hynes et al. 2001). Granular inoculants applied to soils increased seed production, compared to seed-applied inoculants, either as peat powder or liquid (Clayton et al. 2004b). Under field conditions, inoculant applied to soil improved nitrogen nutrition of field pea compared to seed-applied inoculation. The effects of inoculant formulation on nodule number, accumulation of nitrogen, and $\mathrm{N}_{2}$-fixation are ranked as granular peat $>$ peat powder $>$ liquid $>$ uninoculated (Clayton et al. 2004a). An exception to this was demonstrated in Australia, where under intensive field testing (37 field experiments), granules made of either clay or peat were not better than peat slurry inoculants. Their potential niche is when inoculants applied to seeds is problematic, such as when fungicides and insecticides need to be applied (Denton et al. 2009).

Several amendments were added to enhance common formulations of peat with various microorganisms. Several PGPB were added to soilless media made of $70 \%$ peat $+30 \%$ vermiculite in cell trays immediately before sowing seedlings of muskmelon and watermelon. Apart from general growth promotion effect, one PGPB also reduced severity of root knot nematode disease (Kokalis-Burelle et al. 2003). Peat was amended with either chitin, heat-killed Aspergillus niger mycelium or a spent compost from Agaricus bisporus (button mushroom) cultivation. These combinations were used as formulations for Bacillus subtilis for biological control of Fusarium udum (pigeon pea wilt) and Aspergillus niger (groundnut crown rot). These amendments improve growth of $B$. subtilis and, when used as seed treatments, promoted seed germination and biomass of the plant (Manjula and Podile 2001). Cultures of the fungus Trichoderma virens and an agricultural strain of the bacterium Burkholderia cepacia were added to peat supplemented with pyrophyllite (hydrous aluminum silicate); the seeds were also pre-coated with sticky materials before adding the biocontrol agents. This helped to reduce the root-knot nematode Meloidogyne spp. in tomato root explants by inhibiting egg hatching and second-stage juvenile motility (Meyer et al. 2000, 2001). Finally, maize seeds were inoculated by several diazotrophs prior to planting by coating seeds with a suspension of bacteria in peat amended with charcoal and an adhesive to enhance plant growth (Riggs et al. 2001).

Alternatives to peat inoculants, and more popular in the 1980s-1990s, are lignite, charcoal, coir dust, and composts of various origins and compositions, sugarcane filter mud bagasses, soils mixed with various organic amendments, and vermiculite. Most were considered inferior to peat as a carrier (Bashan 1998; Singleton et al. 2002). Nonetheless, some organic inoculants made of several waste materials were tested with significant success in recent years, mainly in developing counties (Ben Rebah et al. 2007). Some were tested on a large scale and others only had inoculant production reported but not its evaluation in situ. For example; application of Fe-enriched, dried plant residues of Azolla was tested on Fe-deficient cucumber plants. The effect of the slowly released $\mathrm{Fe}$ to the nutrient solutions of Fe-deficient cucumber seedlings was compared with additions of several synthetic Fe chelates used for this task. The Feenriched Azolla treatment was found equivalent to FeEDTA and Fe-EDDHA (Plessner et al. 1998). Sawdust amended with nutrients was initially composted by inoculation with a cellulose-decomposing fungus Cephalosporium sp. and the diazotroph Azospirillum brasilense. Yield increases following crop inoculation with the carrier containing the BradyrhizobiumRhizobium-Azospirillum mixture were observed with soybeans, groundnuts, lucerne, and a grass mixture of bird's foot trefoil and ryegrass, compared to a culture 
medium without any additional formulation and uninoculated plants (Kostov and Lynch 1998). Coir dustcoco peat has high moisture-holding capacity of 500$600 \%$ and has good potential as a carrier for PGPB (Prabhu and Thomas 2002). Coco peat might form a part of the solution for the declining availability of common peat because of economic and geographic reasons. Because of high water-holding capacity, non-sterile coco peat can be used for farm-level low-cost, mass multiplication and field application of nitrogen-fixing cyanobacteria (Malliga et al. 1996). Compost made from waste of the cork industry was superior to peat in maintaining survival of several rhizobia and PGPB. This inoculant produced soybean yield not significantly different to those produced by peat-based inoculants (Albareda et al. 2008). Five non-sterile carriers, alginate beads, charcoal, sand, sawdust, and sugarcane bagasse were compared as inoculants for Rhizobium leguminosarum and Pseudomonas fluorescens. Sawdust was the best carrier for maintaining the bacterial population when used individually and together. The co-inoculant was superior in enhancing the seedling biomass and the nodule number of Trifolium repense (Arora et al. 2008). Azotobacter vinelandii was cultured on lignin, derived from Kraft pulping processes in solidstate fermentation. The effects of the ratio of lignin to corn straw, initial water content, and material bed depth, all significantly affected bacteria growth. Under optimum conditions, $A$. vinelandii reached a bacterial population of $42 \times 10^{9} \mathrm{CFU} \mathrm{g}^{-1}$ dry weight after $36 \mathrm{~h}$ (Zhang et al. 2004). Azospirillum lipoferum sp59b was cultivated in diluted olive mill wastewater. It multiplied well and reduced the toxicity of the wastewater. The best multiplication was observed in $10 \%$ olive mill wastewater (Tsagou and Aggelis 2008). These two formulations were not tested on plants. Plant growth-promoting yeasts were grown on moist soybean bran and mixed with soil where disinfected sugar beet seeds were later sown to demonstrate growth promotion (El-Tarabily 2004). Similarly, chitinolytic bacteria and actinomycetes were grown, using wheat bran as a substrate that also served as a carrier by mixing with soil to successfully control the fungus Sclerotinia minor in beans (ElTarabily et al. 2000; Nassar et al. 2003). Municipal and industrial wastewater sludge could be used as a sole raw material to sustain growth of rhizobia (Ben Rebah et al. 2007). Slow- and fast-growing rhizobia grew well in sterile sludge. Sludge composition affected the generation time, cell yield, and nodulation index. Acid, alkaline, and oxidative pre-treatments increased the primary sludge biodegradability and consequently, the cell count of Sinorhizobium meliloti. Pre-treatment of pulp and paper sludge with $\mathrm{NaOH}$ enhanced the concentration of bacterial cells to a maximum $1 \times 10^{10} \mathrm{CFU} \mathrm{mL}^{-1}$, decreased the generation time of bacteria, and reduced the processing time, thus potentially reduced costs (Ben Rebah et al. 2002a, b). Evaluation of barley fiber fractions as growth media and carrier material for the cultivation of the natural bacterial fungicide Streptomyces grisoviridis showed that brewer's spent grain was the best choice, considering price, nutrient content, storage time, and ease of processing of the crude and the finished products. A high content of water-insoluble fiber favorably influenced the appearance and the applicability of the products (Tuomi et al. 2001). Torrefied grass fibers (a new potting soil) was tested as a carrier, using the fungus Coniochaeta ligniaria combined with several PGPB as inoculants for growing tomato plants. Excellent colonization of this substrate by the PGPB, in combination with fungi, create a disease-suppressing substrate that replaced up to $50 \%$ of the peat in potting soil and promoted growth of tomatoes (Trifonova et al. 2009). Comparing the effectiveness of poultry manure and banana waste as inoculant carriers of a consortium of bacteria strains of Azospirillum, Azotobacter, and Psolubilizing bacteria to improve banana plant performance and its soil physical and microbiological properties were measured. Although both inoculants improved plant growth and soil properties, banana waste had a stronger effect (Rivera-Cruz et al. 2008).

In summary, although some organic wastes can perform equally well or better than peat as a carrier, the main limitation is availability of the raw material for industry. Compost made of cork, bagasse, sawdust, brewery waste, or banana leaves can sustain a small, local inoculant industry where the materials are available. They cannot form a base for a large industry, especially when the batch raw material is variable. More consistent raw material, such as sludge derived from the wastewater industry can provide an almost limitless supply of raw material, but this has not yet developed as an inoculant.

Inorganic inoculants

Inorganic inoculants can be made from natural inorganic materials, natural polymers, or synthetic materials. Apart from polymeric inoculants, inorganic inoculants 
are the oldest version of inoculants (for earlier studies: Bashan 1998). While most of these inoculants are used on a small scale for crop production, all polymeric inoculants, as far as we know, are experimental.

Soil-made inoculants

In recent years, scientific reports on soil-made inoculants are few. For example, large-scale cyanobacterial inoculants were produced using soils of their habitats and soils from non-habitats as carrier and cultivated in open air. Nitrogen-fixing cyanobacteria are used sporadically as a supplement to chemical nitrogen fertilizers for rice cultivation in India and Bangladesh. Field trials showed that cyanobacterial inoculants solve problems in acid and saline soils, improve their fertility status, and may add $25-35 \%$ of the nitrogen for rice cultivation in these soils (Hashem 2001). Local strains of PGPB from Vietnam were added to an unsterile carrier formulated by mixing clay soil, rice husks, sugar, water, and broth culture. These bacterial cultures were mixed in the field immediately before inoculating rice seedlings at the time of transplantation, resulting in increased rice yields (Nguyen et al. 2003). Survival of Azospirillum brasilense in turf used as a carrier of several grasses supported viability of $A$. brasilense for 4 months (Garcia and Sarmiento 2000). Using a clay soil inoculant mix with powdered elemental sulfur, inoculation of sulfuroxidizing bacteria (Thiobacillus sp.) along with rhizobia provided a synergistic interaction that promoted yield and oil content of groundnut in sulfur-deficient soils (Anandham et al. 2007).

Few other inorganic materials are used as inoculants. Talc-based formulations are unique inoculants used only in India. Its usefulness has been demonstrated in several agricultural and horticultural crops against pests, diseases, and nematodes under shadehouse and field conditions. Yet, apparently, this formulation suffers from short shelf life, high contamination, and low field performance, but it is still used in experiments (Bharathi et al. 2004; Saravanakumar et al. 2007a, b, 2009).

Perlite and vermiculite, commonly used in plant production substrates, were tested as ingredients for inoculants. Perlite was superior to peat for maintaining survival of several rhizobia and PGPB and enhancing growth of soybeans (Albareda et al. 2008). Inoculum preparation and drying of the formulation are key factors when optimizing the use of a seed formulation. These were tested on survival of the biocontrol bacteria
Pseudomonas fluorescens using a 1:1 the pelleting material $\mathrm{EB}^{\mathrm{TM}}$-vermiculite mix, sugar beet seeds, and amended with nutrients (sucrose-asparagine broth). This resulted in improved survival of the strain in the formulation or on the seeds during storage. A slowerdrying formulation, enhanced survival of the strain during storage. Partial biological control $(\sim 10 \%$ more healthy plants) of Pythium spp. was achieved (MoënneLoccoz et al. 1999).

\section{Polymeric inoculants}

Synthetic formulations based on an assortment of polymers have been continuously evaluated for decades because they offer substantial advantages over peat. These include longer shelf life, appropriate survival at the destination field, sufficient cell density, ease of manufacturing, and improved performance in general (Bashan 1998; John et al. 2011). For agricultural and environmental uses, these polymers include, so far, alginate, agar, $\lambda$ - and $\kappa$ carrageenan, pectin, chitosan, bean gum, and proprietary polymers.

Several basic requirements for these polymers that are components of polymeric inoculants, are: (1) nontoxic and free of harmful preservatives that affect bacteria within the inoculant and inoculated plants, (2) slowly degradable in the soil by soil microorganisms, thereby gradually releasing the bacteria in the needed quantities, usually at the time of seed germination and seedling emergence, (3) provide physical protection for the inoculated bacteria from soil competitors and many environmental stresses (Covarrubias et al. 2012, ZoharPerez et al. 2003), (4) contain sufficient water for survival of the bacteria, and (5) dispersible in water to allow movement of the bacteria from the polymer to the plants.

Additional potential beneficial features are that the inoculants: (1) can be stored dried at ambient temperatures for prolonged periods, (2) offer a consistent batch quality and a better environment for the bacteria, (3) can be manipulated easily according to the needs of specific bacteria (4) can be further amended with nutrients to improve short-term survival of the bacteria upon inoculation, which is essential to the success of the inoculation process. This is especially crucial for associative PGPB competing in the rhizosphere with native microbes. However, the major drawback of polymeric inoculants is that the raw materials for all polymers are relatively expensive compared to peat, soil, and organic 
inoculants and require further more expensive handling by the industry at costs similar to those in the fermentation industry. Consequently, no commercial polymeric inoculants are currently available. Yet, these inoculants may represent the future. A positive aspect of polymeric inoculants is that they are still the domain of research laboratories and not protected by the inoculant industry; hence, relatively more information is available in the scientific literature.

\section{Encapsulated formulations}

The encapsulation of microorganisms in a polymeric matrix (also known as immobilization when one microorganism is used and co-immobilization when more than one organism is used) is currently experimental in the field of agricultural and environmental bacteriainoculation technology. The basic industrial concept underlying immobilizing microbial cells is to entrap live microorganisms into a polymeric matrix and maintain their viability. The immobilized product (bacteria-synthetic matrix) is then fermented in a bacterial growth medium for different end uses. These formulations can produce many useful compounds for industrial applications, including organic acids, amino acids, enzymes, and vitamins, and environmental applications, including bioremediation of toxic materials for extended time periods. The desired bacterial products are extracted from the bioreactor while fermentation continues. Immobilized microbial cells are easy to produce, store, and handle during industrial operations. The main goal of these industrial formulations is to maintain the entrapped cells in an active form, at high concentrations, for as long as possible. Any premature release of the microorganisms from these encapsulated forms is undesirable (Fig. 3). These industrial-end formulations are not the topic of this review and can be viewed elsewhere (Prasad and Kadokawa 2009). Encapsulated bacterial formulations for agricultural and environmental applications have at least two distinctly different goals from those of the fermentation industry: (1) They have to provide a temporary shelter for the encapsulated strain from the soil environment and from microbial competitors, both hostile to any change in the biological makeup of the soil, and (2) for colonizing plant roots, they have to release the desired strain gradually. Liberation of the entrapped bacteria from the beads happens when the polymer is slowly degraded by the native soil microorganisms, thereby releasing the PGPB-rhizobia to the soil where plants that need inoculation are growing (Fig. 3).

\section{Macro- and micro-formulations of alginate}

So far, alginate is the material of choice for most encapsulations of microorganisms. The formulations are used for various purposes: immobilization of cellular organisms and enzymes, application of biological control agents and mycoherbicides, increase the stability of recombinant plasmids in host cells, bacterial chemotaxis research, mushroom cultivation (Prasad and Kadokawa 2009), and a primary polymer in formulations of drugs (Tonnesen and Karlsen 2002). Alginate is a naturally occurring polymer available mainly from different marine macroalgae in large sustainable quantities (Draget et al. 2002; Yabur et al. 2007), as well as from several bacteria (Sabra et al. 2001; Trujillo-Roldán et al. 2003). The preparation of beads containing bacteria is fairly easy, straightforward, and involves a multi-step procedure at room temperature with minimal amounts of additional chemicals and equipment; thus, it is popular in research. Diagrams of procedures are available (Bashan et al. 2002; de-Bashan et al. 2004; de-Bashan and Bashan 2010). In cases where the biomass of the entrapped bacterial strain is low, a secondary multiplication of the entrapped bacteria in the already-formed beads is required (Bashan 1986a, b). The advantages of alginate formulations are their nontoxic nature, biodegradability, availability at reasonable costs, and slow release of the entrapped microorganisms into the soil that is controled by the polymeric structure (Bashan et al. 2002; Zohar-Perez et al. 2002).

\section{Macro-alginate beads}

The technology of macro-alginate beads (1-4 mm dia) was used to encapsulate several plant growth-promoting bacteria and mycorrhizae fungi. For example: Streptomycetes sp. was formulated in an alginate-kaolin (aluminium silicate) carrier. First the bacteria were mixed with the kaolin, then mixed with alginate and formed into beads. Finally, the formulation was lyophilized. This dry formulation was further formulated as a dry or wettable powder by adding starch, talcum, and more kaolin to enhance survival of Streptomycetes $\mathrm{sp}$. in the inoculant for 14 weeks. Testing these formulations showed large variations in biocontrol efficacy of the 


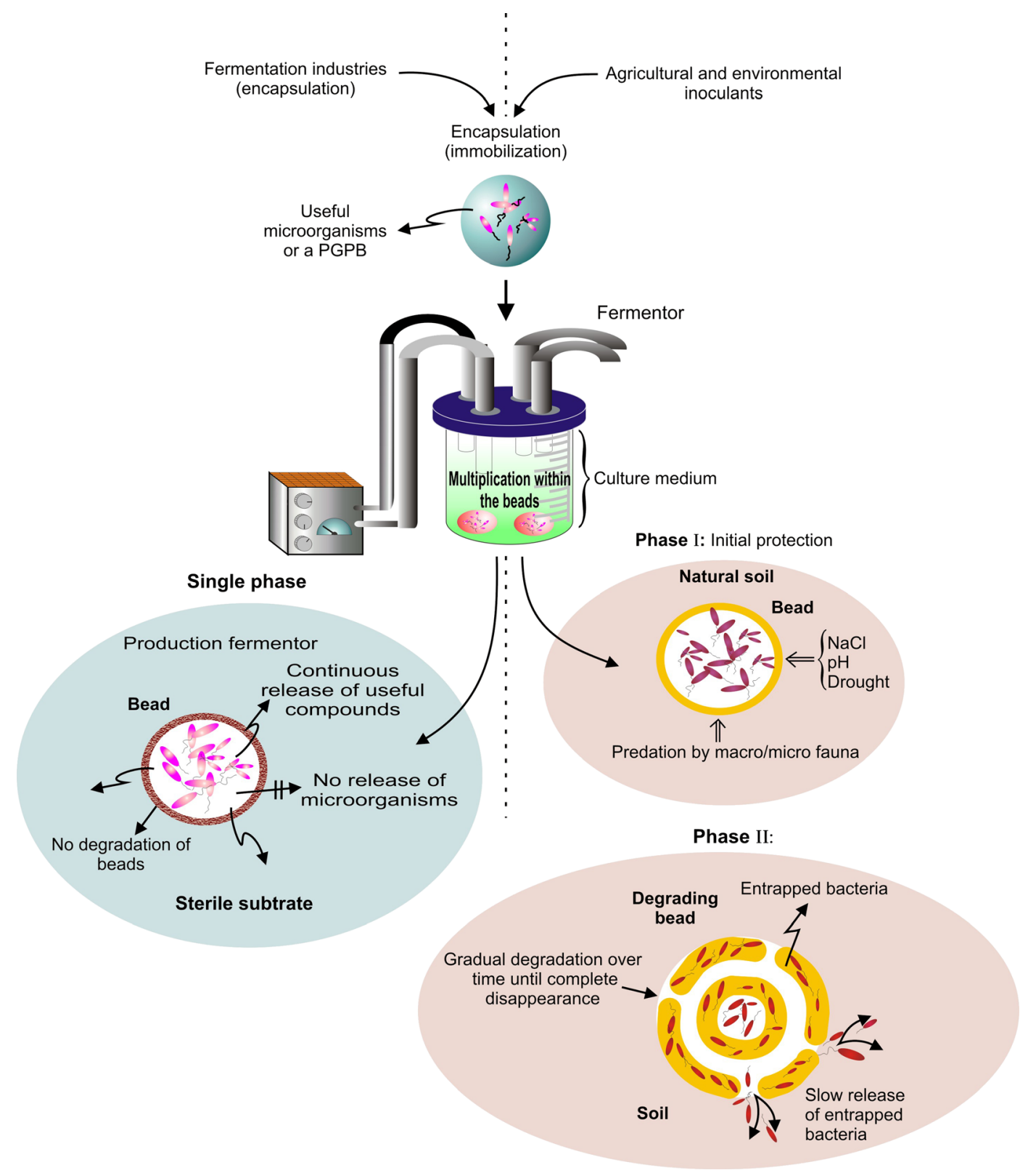

Fig. 3 Comparison between encapsulation of bacteria for use in industrial fermentation and as an inoculant for agricultural/environmental use

fungal pathogen Rhizoctonia in tomato (Sabaratnam and Traquair 2002).

Encapsulation of the PGPB Bacillus subtilis in alginate beads enriched with humic acid yielded high viability of the encapsulated bacteria with minimum cell loss during storage for 5 months. For 1 week at different $\mathrm{pHs}$, this formulation yielded steady and constant cell release from the bead. Successful plant growth promotion of lettuce by the encapsulated bacteria was demonstrated (Young et al. 2006). Feasibility of this improved encapsulation technique is mainly from the dual benefits of humic acid to the microbe and plant and its chemical properties, allowing an easy mixing with alginate without interfering in the formation of the alginate gel beads by cross-linking with $\mathrm{Ca}^{2+}$ ions (Young et al. 2006). The benefit of the presence of humic acid in the structure of alginate bead is its role of serving as a carbon source to the encapsulated PGPB P. putida and 
B. subtilis, a fact that might also helped survival of both bacteria in beads during storage (Rekha et al. 2007).

Far longer survival time in dry alginate bead was detected. Two PGPB, Azospirillum brasilense and Pseudomonas fluroescens, immobilized in two types of alginate-bead inoculant (with and without skimmilk supplement) and later dried and stored at ambient temperature for 14 years, were recovered. The population in each type of bead had decreased, yet significant numbers survived $\left(10^{5}-10^{6} \mathrm{CFU} / \mathrm{g}\right.$ beads). Population numbers depended on the bead type. When inoculated on wheat plants under gnotobiotic conditions in growth pouches in a growth chamber, both species colonized and produced plant-growth effects equal to those of their contemporary strains (Bashan and Gonzalez 1999). Vassilev et al. (2001) show that inoculation of tomato plants with an AM fungus (Glomus deserticola) and a Psolubilizing microorganism (the yeast Yarrowia lipolytica) entrapped in alginate can be an efficient technique for plant establishment and growth in nutrient deficient soils. Several plant growth parameters were equal in treatments inoculated with free and alginateentrapped AM but dual inoculation increased all analyzed variables. Highest rates of the latter were obtained when both fungal microorganisms were entrapped in the carrier. The yeast culture behaved as a "mycorrhiza helper microorganism", enhancing mycorrhization of tomato roots.

Wet alginate inoculant used as spawn of the white mushroom (Agaricus bisporus) had a shorter adaptation (lag) period and a higher growth rate in pasteurized compost than both liquid spawn and the conventional grain spawn. The superiority of this delivery system is attributed to the high biomass loading capacity of these beads, mycelial protection in the bead microenvironment, and the spatial distribution of the beads in the compost (Friel and McLoughlin 1999). Protection against high temperatures can be supplied by formulation of alginate. Alginate formulation supported high populations and survival of the phosphate-solubilizing bacteria Pseudomonas striata and Bacillus polymyxa at the elevated storage temperature of $40^{\circ} \mathrm{C}$ (Viveganandan and Jauhri 2000). Several alginate formulations (macrobeads with and without skim milk and seed coating) of B. subtilis and Pseudomonas corrugata were found superior over liquid inoculants or charcoal-based inoculants for inoculating maize plants under low temperatures in the Indian Himalayas (Trivedi et al. 2005).

Another application of alginate inoculants is in tertiary wastewater treatment by microalgae (de-Bashan and Bashan 2010). A combination of microalgae (Chlorella vulgaris or C. sorokiniana) and a microalgae growth-promoting bacterium (MGPB, Azospirillum brasilense), co-immobilized in macroalginate beads, was developed to remove phosphorus and nitrogen nutrients from municipal wastewater. Co-immobilization of the two microorganisms provided superior results for removing these nutrients than the microalgae alone (deBashan et al. 2002a, b, 2004; Hernandez et al. 2006; Covarrubias et al. 2012; Cruz et al. 2013). The debris from the wastewater treatment, alginate beads containing the two microorganisms, were used to improve growth of sorghum and enhance fertility of eroded desert soil (Trejo et al. 2012; Lopez et al. 2013).

Alginate preparations may have solved many of the problems associated with common peat inoculants (Bashan 1998, Table S1); yet, application of the commonly used macro-alginate beads as agricultural and environmental inoculants have two major disadvantages. First, an additional treatment during sowing is needed even if the inoculant is planted by the seeding machine (discussed later). In developed countries, the grower who is busy during sowing, might be pressed for time and reluctant to incur additional expense and time. In developing countries, the farmer might not inoculate the seeds at all. This happens because of insufficient agricultural education and conservative cultural traditions that make some small-scale farmers suspicious of new technologies, especially those involving live bacteria. Second, the bacteria released from the inoculant needs to move through the soil toward the plants. Under agricultural practices, when beads are loosely mixed with seeds and sown together by planters, the inoculant beads might fall far from the seeds (up to a few centimeters). Thereafter, the bacteria released from the beads must migrate through the soil, facing competition from the native microflora, sometimes more aggressive and more adapted to the soil than the inoculated strain. Sometimes, the absence of a continuous film of water needed for their movement is an additional limiting factor. These distances, large on a microbial scale, might prove prohibitive for many PGPB, even those with a proven motility in soil like Azospirillum (Bashan and Levanony 1987).

Micro-alginate beads

The microbead concept (50-200 $\mu \mathrm{m}$ in dia) was conceived to overcome these two fundamental difficulties. 
The underline hypothesis is that, if the beads are small enough, yet still capable of encapsulating a sufficient number of bacteria, it would be possible to produce a "powder-like" formulation similar to powdered peat inoculants. The seeds are coated with this "bead powder" at the seed-handling facility and sold to the farmer as "improved seeds". Coated seeds (but with fertilizers, fungicides, or hormones) are commonplace and accepted in most farming communities worldwide. In developed countries with large scale agricultural practice, such as North America, pre-coated seeds will eliminate the need for an additional expensive field treatment and provide the ultimate convenience for the grower. This significant benefit notwithstanding, pre-coating seeds with PGPB is not an easy industrial task and, so far, has been done only on an experimental scale. Yet, a similar formulating idea, but with peat inoculant, has been applied commercially for a long time as a preinoculation of forage legumes, such as alfalfa. The peat is applied to the seeds as a slurry; an adhesive and inoculated seeds are covered with finely-ground calcium carbonate (Brockwell 1977).

The production of alginate microbeads is simple and involves low pressure spraying through small nozzle resulting in small-diameter droplets of an alginate solution mixed with liquid bacterial culture suspended in a very rich medium (equipment presented at Bashan et al. 2002). These droplets, while sprayed into a slowly stirred solution of $\mathrm{CaCl}_{2}$, immediately solidify into microbeads at diameters ranging between 100 and $200 \mu \mathrm{m}$, which entraps a large number of bacteria $\left(\sim 10^{8}\right.$ to $10^{10} \mathrm{CFU} \mathrm{g}^{-1}$ ) (Bashan et al. 2002), similar to the population levels entrapped in alginate macrobeads (Bashan 1986a, b). An alternative proposal to the small nozzle method to produce microbeads is that the size of calcium alginate gel beads can be controlled by application of high voltage to an interface between an aqueous alginate solution and an organic phase containing a surfactant that affects the size of the alginate solution droplets. These can vary from a few millimeters to a few hundred micrometers with an increase in applied voltage. The formed droplets are then conventionally hardened by $\mathrm{CaCl}_{2}$. So far, this last idea has not been applied to any useful microorganisms, apart from baker's yeasts (Murakata et al. 2001).

Application of microbead alginate formulations to inoculate plants in the soil was done a few times. These included: (1) Using several transplanted desert tree species and cacti in desert reforestation programs.
These long-term (5 y), successful shade house and field experiments used $A$. brasilense and PSB entrapped in microbeads, where the inoculant was added to the planting hole beneath the root balls (Bashan et al. 2009a, b, 2012). (2) Cells of Pseudomonas fluorescens were encapsulated in 300 to $700 \mu \mathrm{m}$ alginate microbeads. The survival of the microorganisms and ability to colonize sugar beet were measured after 1 year. Although dried alginate beads yielded a significant reduction of viable bacteria, the microbeads enabled a satisfactory level of root colonization and protection against the pathogenic fungi Pythium ultimum and Rhizoctonia solani. The capability of the encapsulated cells to produce the antifungal metabolite 2,4-diacetylphloroglucinol was not significantly affected after storage for 12 months (Russo et al. 2001). (3) Biological control was used against the red fire ant Solenopsis invicta, using alginate beads containing the entomopathogenic fungus Beauveria bassiana and coated with peanut oil. Broadcast applications and individual mound treatments by this inoculant reduced activity of $S$. invicta populations (Bextine and Thorvilson 2002).

\section{Potential improvements of micro-alginate beads}

Because food, pharmacology, nanotechnology, and cosmetics are the larger research fields employing immobilization, several technical improvements derived from these fields, aiming to make the polymer more suitable for immobilization of biological materials, were proposed. Although these were done without specific reference to agricultural/environmental inoculants, they may provide insight for future developments (John et al. 2011; Schoebitz et al. 2013). Three examples with potential for inoculant production are provided here. (1) Biotin was co-valently coupled with alginate in an aqueous-phase reaction as a biotin-alginate conjugate. This new immobilization material combines the advantages of alginate gelling properties to entrap cells providing them with a gentle hydrated and highly porous environment and the high affinity interaction of the avidin-biotin system. The conjugate was successfully used to encapsulate bioluminescent reporter cells into microspheres (Polyak et al. 2004). (2) Alginate hydrogels can be reinforced at the surface with several secondary polymers to enhance their mechanical strength and stability to extend degradation time in soil, if needed (Bashan 1986a; Nussinovitch 2010). Common alginate hydrogels were reinforced with 
polyethyleneimine (PEI) leading to higher elasticity than gels with no PEI. The stable interactions between the alginate and PEI prevented alterations of the pore structure in the gels and slowed the deterioration of gel properties even under continuous agitation in a bioreactor (Kong and Mooney 2003). Stability of barium alginate beads could be improved by a multilayer coating with PEI and polyacrylic acid (Gaumann et al. 2000). Short-chain alginate was synthesized and used for coating the capsular membranes of microcapsules to provide excellent mechanical strength (Chang et al. 2002). To extend degradation time, a chitosan-alginate- $\mathrm{CaCl}_{2}$ system was evaluated to produce water-insoluble membranes of biodegradable polymers to attain maximum mechanical strength (Wang et al. 2001). While it would be wiser, under common agricultural application, to have water soluble membranes on the microcapsules, given that microbes need to be released and the solvent in soil is water. (3) A method to form macroporous beads with an interconnected pore structure from alginate was developed to improve growth and survival of microorganisms by incorporating gas pockets within alginate beads, stabilizing the gas bubbles with surfactants, and subsequently removing the gas (Eiselt et al. 2000).

In summary, technically, it appears that alginate is the most promising of the encapsulating materials tested so far. However, because of the limited published research on alginate beads related to agriculture/environment and because of their higher price compared to peat, it is premature to predict whether alginate will displace peat in the agro-inoculation industry or will remain only in the domain of industrial and environmental microbiology where it runs supreme.

Polymeric inoculants with other materials

Although commercial alginate preparations are not yet available for bacterial plant inoculation, several other materials that are used in industrial and environmental microbiology may be considered as substitutes when the microorganism fails to adapt to alginate preparations. Even though all materials are still experimental, this review mentions them to promote further research with these carriers. Earlier cases are listed in Bashan (1998).

Several PGPB were formulated using chitosan as a carrier mixed with soilless growth medium for successful biological control against cucumber mosaic virus in tomato (Murphy et al. 2003). Five PGPB were prepared into several formulations of polymers composed of carboxymethylcellulose starch. These formulations maintained the bacterial strains in high numbers for 60 120 days of storage. The formulations were effective in promoting the growth of sugarcane cuttings (da Silva et al. 2012). Rhizobia that were formulated in the same inoculants kept their populations inside the inoculants for 165 days of storage and were capable of promoting growth of cowpea (Júnior et al. 2009). The PGPB Pseudomonas fluorescens was formulated for three polymers: commercial film-forming "methacrylic acid copolymer" (Evonik Industries, Darmstadt, Germany), ethylcellulose, and a modified starch. The best performer was the commercial polymer; bacteria survived for 1 year. A relationship was found between survival of bacteria and the microspheres' residual moisture; the highest survival of the bacteria occurred when the residual moisture was around $25 \%$. This inoculant was not tested on plants (Amiet-Charpentier et al. 1998). Because so little information is available on these potential carriers, it is impossible to predict their future as bacterial inoculants.

\section{Dried polymeric carriers}

A main objective of encapsulating bacteria for agricultural and environmental use, similar to other inoculant types, is to increase shelf life, rather than maintain a high bacterial count, since the number of bacteria usually decreases during storage (discussed later). From commercial and agricultural standpoints, longer survival of bacteria in these polymeric preparations makes dry formulations very attractive.

There are several cases regarding dry alginate inoculant. Dry seed coats of various formulations of alginate alone or with bran and chitin additives without PGPB did not affect the viability or germination percentage of seeds of wheat, basil, cabbage, and radish (Sarrocco et al. 2004). A microbead formulation containing $A$. brasilense was air dried at $38^{\circ} \mathrm{C}$, creating a powdery substance; each bead contained $>10^{9} \mathrm{CFU} \mathrm{g}^{-1}$ bacteria. Alternatively, dry microbeads were produced using a standard freeze-drying procedure. This dry preparation was easily attached to dry seed surfaces with the addition of lecithin or with synthetic paper adhesive. The bacteria were slowly released from the microbeads in amounts ranging from $10^{4}$ to $10^{6}$ CFU g microbeads ${ }^{-1} \cdot \mathrm{d}^{-1}$, depending on the formulation and the time of incubation (the longer the 
incubation period, the fewer bacteria were released). The dry inoculants enhanced development (dry weight, height of plants) of wheat and tomato seedlings growing in infertile soil and was biodegraded within 15 days in moist soil, using a scale of degradation (Bashan et al. 2002). A microbead formulation used for desert reforestation (mentioned above) were air dried in flat trays at $30{ }^{\circ} \mathrm{C}$ for $24 \mathrm{~h}$ without loosing efficacy (Bashan et al. 2009a, b, 2012). The efficacy of freeze-dried alginate beads was tested with an agricultural strain of Pantoae agglomerans. The dry beads were produced with bacteria, glycerol, and chitin in the mix. Glycerol increases pore size within the beads, which affects the slow release properties, where addition of glycerol and chitin enhanced survival during the freeze-drying process. These beads were able to protect the applied PGPB to the soil compared to bacterial suspension (Zohar-Perez et al. 2002).

\section{Inoculation techniques}

PGPB (including rhizobia) can be inoculated directly on the seed surface or into the soil. Seed applications greatly outnumber soil applications. Each method has advantages and disadvantages, depending on the requirements for specific inoculation, the type of seeds, and the amount of inoculant. For example, inoculation of large seeds in a large-scale operation involving many metric tons of seeds and requires a different approach to that required for sowing pasture seeds where only a few kilograms of seeds are required. The techniques need to address inoculation under adverse situations, such as high temperature exposure of an air seeder, rapid drying when the inoculant is sprayed into sowing machinery, when inoculated seeds are sown under hot, dry conditions, or when seeds are treated with fungicides and herbicides (Date 2001).

\section{Seed inoculation}

This is the most common and practical inoculation technique. This happens because it is easy to use and requires a relatively small amount of inoculant. There are many small variations of the basic technique. Using a variety of machinery, the basic technology of even seed-coating has not changed for decades. Several reviews from the 1970s (listed in Deaker et al. 2004) summarize the fundamentals, which are similar in all procedures. Briefly, prior to sowing, seeds are dusted with peat inoculant, with or without water or adhesive. For small seeds, this is followed by superfine, ground limestone, with or without adhesive, and allowed to dry. Drying can be done in situ or when the coating is applied prior to sowing. The seeds, held in shallow trays, are airdried or dried by forced air. Coating and drying using fluidized beds where the seeds are floated on a cushion of pressurized air and then sprayed with inoculant and later coated with ground limestone has proved, at least for rhizobia, less successful. Good pellets are evenly coated with limestone, are dry and without loose limestone on the surface, have good structural integrity, and are firm enough to withstand soft impact when dispensed in seeding machinery. Dislodged coating material might block seeding machinery.

The inoculant is mixed with seeds either by hand, rotating drums that are cheap to operate, large dough or cement mixers, or mechanical tumbling machines (Schulz and Thelen 2008). Alternatively large farm operators use automated seeders fitted with an inoculant tank, pump, and a mixing chamber commonly used for applying chemical coatings. As these are not specialized equipment for microbial inoculation, the inoculant may dislodge from the seeds.

Because every seed needs to be coated with a threshold number of bacteria, adhesives are used. Adhesives include gum arabic (Wani et al. 2007), carboxy methyl cellulose (Viji et al. 2003), sucrose solutions (Cong et al. 2009), vegetable oils (Bashan et al. 2002), as well as any non-toxic commercial adhesive to the bacteria and seeds. A second role of an adhesive is to prevent the inoculant (either dry inoculant as powder or wet inoculant once the moisture evaporates) from dislodging during sowing with the seeding equipment, especially the powderedtype when applied with air-seeders. Sometimes, pelleting of seeds with superfine limestone $\left(\mathrm{CaCO}_{3}\right)$ is added to balance the acidic nature of the soil. This can be done with an additional adhesive layer under the lime coating (for older cases, see: Deaker et al. 2004). The seeds are then sown with common seeding equipment. It is commonly agreed that one essential condition to seed coating is adding adhesive materials. Yet, there is no agreement on the best adhesives. Each manufacturer or experimentalist empirically evaluates which adhesive best fits seeds and inoculants (Albareda et al. 2008, 2009). When seeds are inoculated with liquid inoculant, with or without dissolved adhesive, the inoculant is sprayed directly onto the seeds. After drying, the seeds are sown (Fig. 4a). 
Fig. 4 Schematic representation of a seed inoculation and b soil inoculation a

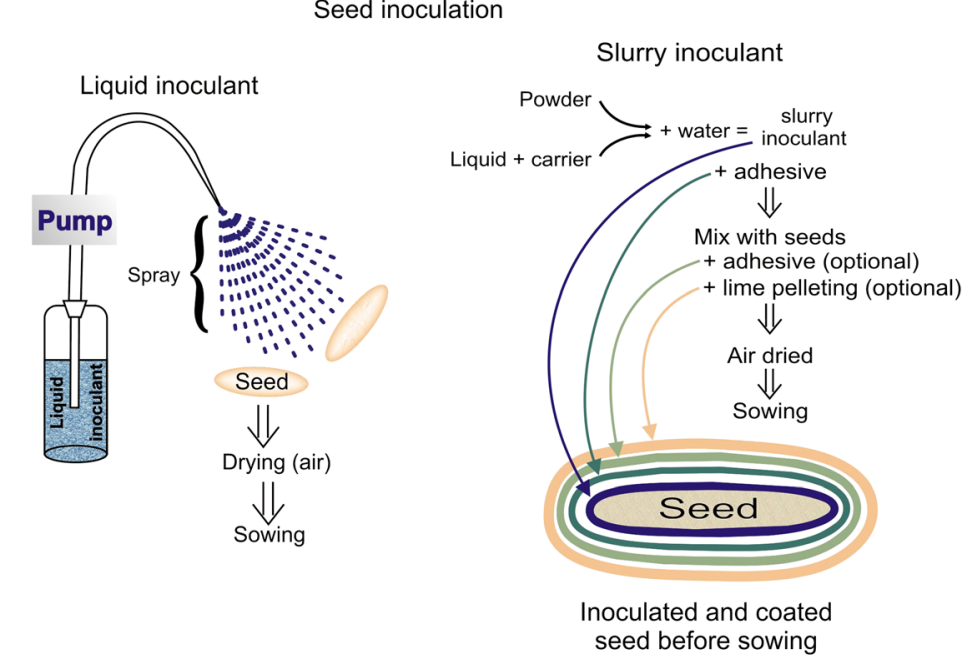

b Soil inoculation

= Pellets $(0.5-1.5 \mathrm{~mm})$ : peat, perlite, charcoal, soil aggregates Furrows
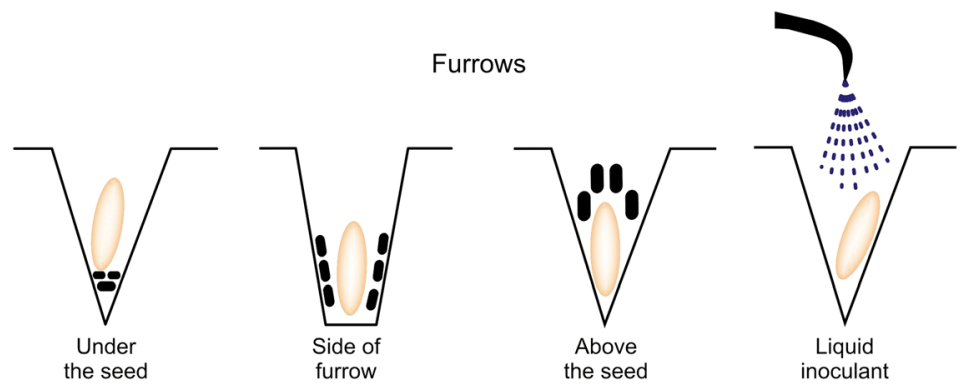

Seed inoculation has several disadvantages. Each seed, especially small ones, can be coated only with a limited amount of inoculant, which may be a limiting factor because a threshold of bacteria may be needed for successful inoculation with most PGPB. If an inoculant is not attached well with an adhesive or by pelleting, it may be dislodged by the sowing machinery. In some seedlings, the seed coat is lifted out of the soil during germination, causing desiccation and death of the inoculant bacteria if the inoculant had been applied directly to the seeds. If the inoculation process damages seed coats that are delicate (peanuts, for example) this may prevent germination. Some species release anti-bacterial compounds from their seeds, which can inhibit the inoculant. Some fungicides and insecticides applied to the seeds may be detrimental to the inoculant.

Soil inoculation

This technique is used when a large population of a bacterial strain should be introduced to the soil.
Although standards for rhizobia are usually the same (in CFU $\cdot \mathrm{ha}^{-1}$ ) as they are for inoculants applied to seeds, application of high quantities by soil inoculation removes several constraints that are described below. Usually granular inoculants $(0.5-1.5 \mathrm{~mm})$ are placed in the seedbed under, above, or alongside the seed at sowing time. Granular inoculants must be free-flowing, dry, and aggregate-free when applied by seeding machinery. This approach is popular in North American possibly because granules are easy to apply, less dusty than powder inoculants, and massive inoculation improves field performance of microorganisms (Xavier et al. 2004) (Fig. 4b).

There are several major advantages for granular inoculants. Paramount is the ability to control the location and the application rate of the inoculant. This technique avoids damage to seed coats and protects the inoculant from adverse effects of pesticides and fungicides applied directly to the seeds. The physical separation between the inoculant and the seeds is overcome with emergence of the seedling roots growing into the adjacent 
inoculant. Inoculation of the soil reduces the risk of loosing part of the inoculant when the seeds pass through the seeding machinery. Small seeds benefit from soil inoculation because they can be exposed to higher concentrations of inoculant than with seed-coat inoculation. Granular inoculants are especially suitable for farming in developed countries where the machinery for seeding commonly includes accessories for application of fertilizer and pesticide and inoculation is just one additional input during seeding.

Granular forms of peat, marble combined with peat, perlite, charcoal, or soil aggregates are suitable for soil inoculation. This technique enhances the chance for the inoculant to be in contact with plant roots. A derivative of soil inoculation is to use liquid inoculants. Slurries of peat inoculants and liquid inoculant were successfully applied directly to soil or hydroponic systems.

There are also disadvantages when inoculating soils, mostly technical. Inoculation of soil requires specialized equipment and larger quantities of inoculants are generally required, thus, increasing costs. Larger quantities require more storage area and transport, which also increases costs, making this type of inoculation, in general, costlier than inoculating seeds.

The method of choice depends on the availability of equipment, seed size, fragility of the seed coat and cotyledon, presence of fungicides applied with the seeds, convenience for the grower, and the price that the grower is willing to pay for the inoculant (Deaker et al. 2004).

\section{Technical aspects of inoculant production}

While this section is primarily the domain of production facilities for inoculants, these aspects are interlinked with formulation and application of inoculants. They form one chain of events linking research facilities to the industry and the farm; the latter might be agricultural or environmental.

\section{Culture production}

For every PGPB/PGPR/rhizobia there is an available culture medium to produce it. While most were developed for laboratory handling of microorganisms (Bashan et al. 1993), they do not yield sufficient mass for production of inoculants. Many media incorporate refined chemicals whose costs are prohibitive for mass production of microorganisms. Yet, some media formulations were developed specifically for mass production of inoculum, such as the case of Azospirillum (Bashan et al. 2011) and rhizobia (Singleton et al. 2002). Many proposals for cheap mass cultivation of microorganisms is to use by-products of food processing, such as cheese whey, corn steep liquor, malt sprouts, and malt bagasse that may serve as appropriate sources of carbon. Yet, the quality of the raw material for routine industrial production is questionable and deserves additional studies (Stephens and Rask 2000). The easiest part of microbial cultivation is the fermentation process. Although a precise protocol for production of each strain must be established, the existing fermentation industry is capable of handling any promising strain that the inoculant industry may desire.

\section{Sterilization}

Sterilization of the carrier material is essential to keep high number of the desired bacteria in the final formulation for long storage periods. It is common knowledge that contaminants have detrimental effects on shelf life of inoculants (earlier studies used exclusively for rhizobia). Yet, many carriers, especially in developing countries, are non-sterile because of the costs. The cheaper non-sterile inoculants have a much larger share of the market and possibly a greater sales potential in less industrialized markets.

Sterilization is essential for the growth and survival of slow-growing PGPB, such as Bradyrhizobium spp. This will allow these PGPB to out-compete faster growing contaminants (Deaker et al. 2004). The current trend is to produce contaminant-free inoculants and quite a few (mainly for rhizobia) exist in the marketplace. Using $\gamma$-irradiation is the most suitable way to sterilize any carrier because the sterilization process makes almost no change to physical and chemical properties of the material. Practically, carrier material is packed in thin-walled polyethylene bag and then $\gamma$-irradiated. Several inoculants were tested after $\gamma$-irradiation demonstrating no contamination problem (Albareda et al. 2008). The main disadvantages of nuclear sterilization are elevated cost and slowness (hours of exposure). Apart from costs of the sterilization process, other disadvantages of nuclear sterilization is to find a sterilization unit with fast handling and sufficient capacity and the need to inoculate the desired PGPB into the carrier 
under sterile conditions by skilled personnel, further increasing costs.

A feasible alternative for carrier sterilization is autoclaving because autoclaves of all shapes and sizes are commonplace and this can be done by unskilled personnel. Carrier material is packed in partly open, thin-walled polypropylene bags and autoclaved for $60 \mathrm{~min}$ at $121{ }^{\circ} \mathrm{C}$. A better alternative, yet, costlier is tyndallization. In this type of sterilization, three independent sterilization procedures are carried out each daily incubating at optimal bacterial growth conditions $\left(25-30{ }^{\circ} \mathrm{C}\right)$ for $24 \mathrm{~h}$ in between. This allowed spores of contaminating microorganisms to germinate, and the vegetative cells are destroyed in the subsequent autoclaving. While autoclaving functions well on substrate for liquid inoculants (mainly chemical and byproduct of other industries listed above), the disadvantages of autoclaving organic materials are considerable. The procedure is laborious because of large volume; there is high energy cost; it is time consuming, and most importantly, some organic materials change their chemical properties and may produce toxic substance to some bacteria during autoclaving. Still, autoclaving is favorable for several rhizobia strains that survive in sterile peat inoculant far better than under non-sterile conditions (Temprano et al. 2002).

\section{Shelf life}

Liquid inoculants produced in the field by fermenters and immediately applied are uncommon and only a few exist for turf grass for golf courses and limited hydroponic cultivation. For common agricultural uses, inoculants made of peat or other organic and inorganic materials and a storage period between manufacturing and use, is usually required. Extended shelf life of the inoculant, while retaining its biological traits intact, is $a$ major challenge for any formulation (Fig. 5). So far, the most common solutions to this fundamental problem of extending survival time have been to reduce moisture in the formulation, produce dry formulation by drying in either a fluidized bed, air-dried, or lyophilized (all causing lower water content in the final product), or store at cooler temperatures. In completely dry formulations, bacteria remain in a dormant form, its metabolism is very slow or even stopped, and are resistant to environmental stresses, insensitive to contamination, and are more compatible with fertilizer application.
The main difficulty with most techniques is survival of the microorganisms during the dehydration process and storage, reaching mortality $>90 \%$ of the initial incorporated population. The dehydration phase is perhaps the most critical and the most stressful for microbes during the formulation process. This is an acute difficulty for non-spore-forming, Gram-negative bacteria, which are the majority of species among the PGPB. Additional stress is reviving the bacteria at the time of inoculation, which produces hydration stress on the cells. Survival is affected by several variables: the culture medium used for raising the bacteria, the physiological state of the bacteria when harvested from the medium, the process of cell encapsulation, the use of protective materials, the type of drying technology, and the rate of dehydration. If properly dehydrated, the shelf life of the dried formulation is much longer than any moist product. Drying during formulation is a crucial step. The highest death rate occurs either soon after manufacturing, while in storage, or immediately after application to the seeds or soil (Date 2001).

When a moist formulation, such as peat, is used, moisture content of $40-50 \%$ proved optimal for growth and survival of a range of rhizobia (Deaker et al. 2004). Consequently, a practical solution, for example, to improve survival of rhizobia on seeds is a short curing period of $15 \mathrm{~d}$ at $25^{\circ} \mathrm{C}$ or an even longer curing time of up to 120 days, which is better. This curing favors adaptation of rhizobia to the carrier and increase tolerance to drying (Albareda et al. 2008). All this happens because rhizobia are metabolically active and as long as nutrients and favorable environmental conditions prevail, they continue to grow inside the inoculant. When the bacterial population declines from dehydration, the surviving numbers are higher. Short-term storage is highly affected by temperature. Using various organic, inorganic, and polymeric formulations, Bacillis subtilis survive at room temperature $\left(\sim 22^{\circ} \mathrm{C}\right)$ for 45 days, but Pseudomonas putida requires refrigeration $\left(\sim 0{ }^{\circ} \mathrm{C}\right)$ and depends on the type of carrier that is used (Amer and Utkhede 2000). When $\gamma$-irradiated cork compost or perlite inoculants, with zero contamination, were stored at $25{ }^{\circ} \mathrm{C}$, rhizobia in these inoculants remained unchanged for 90-120 days of incubation; inoculants composed of two clays maintained a high bacterial population for more than 5 months (Albareda et al. 2008).

The commercial literature found on the Internet agree that shelf life of 1-2 years under warehouse conditions for peat inoculants is desirable and the storage time is 
Fig. 5 Improving shelf life of inoculants
Shelf-life

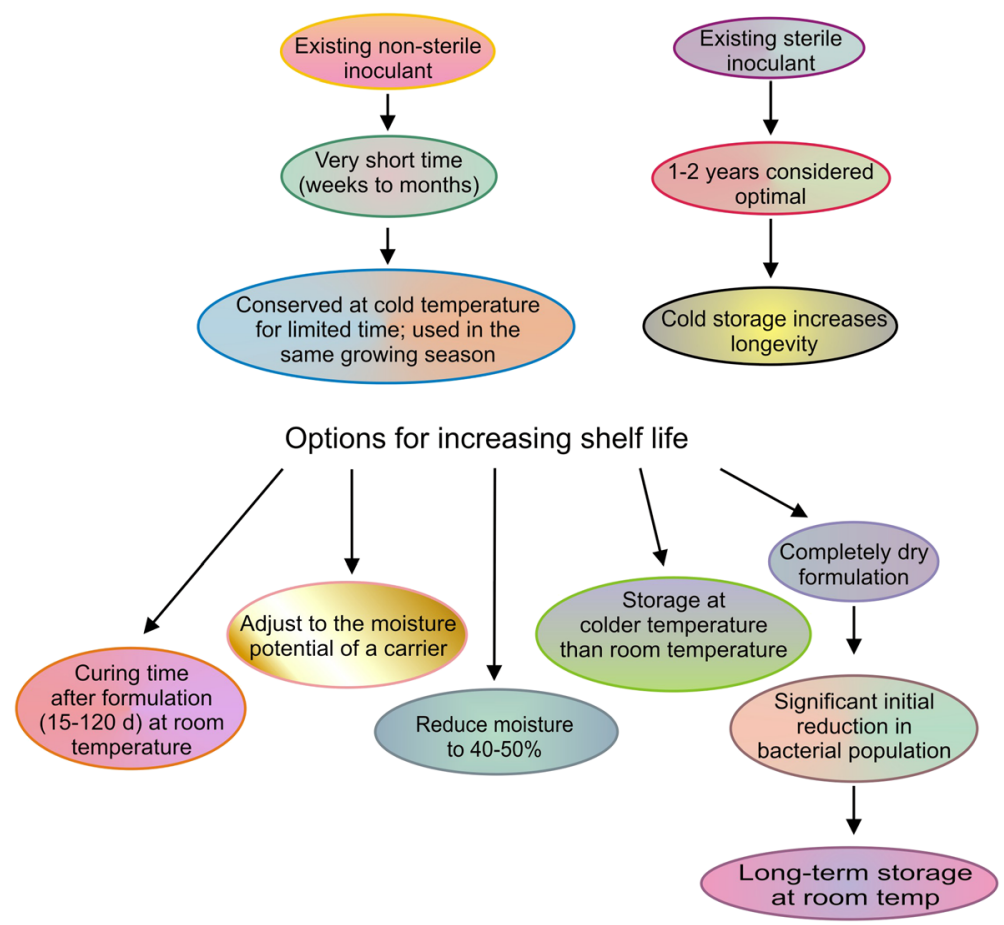

microbes in the inoculant, so despite in decline in population over time, enough cells remain alive at seeding time. Alternatively, use an additive in the formulation to increase growth during storage or maintain cold storage that reduces the rate of decline in bacteria. In this case, even formulations with lower starting populations can be acceptable (Xavier et al. 2004) (Fig. 5).

\section{Future prospects}

Developing new and effective formulations for inoculation of PGPB and rhizobia is a very slow process, regardless of the consensus that this issue is high on the list of developments of inoculation technology. Creation of new formulation is a challenge in practical microbiology. Improvements in formulations are key to the development of enhanced high-end inoculants. Literature surveys show that the identification of new isolates having PGPB capacities is often not difficult and many are identified annually. Yet, most PGPB strains stop there, without ever reaching the formulation stage.

While several thousand articles describe inoculation of plants with microorganisms, only a handful concentrated on delivery systems. Mostly, formulations and 
applications are hidden within the Materials and Methods section of articles on other topics. Grant applications regarding formulations are seldom successful. This topic, which spans basic and applied research done simultaneously in research facilities and commercial agricultural fields, is largely neglected. Yet, for the future of plant inoculation, this topic cannot be ignored.

In the last decade, there has been increased interest in improving the quality of inoculants by using more contaminant-free inoculants than inoculants with nonsterile carriers that, for many years, performed poorly, especially for rhizobia. Non-sterile carriers prevail because of the absence of formal standards in most countries that produce inoculants. However, in countries with high standards and governmental control over quality of inoculants, the trend is to increase quality using sterile carriers or liquid, sterile-based inoculants to avoid contamination. This also maintains high number of rhizobia-PGPB for at least 1 year of storage at room temperature. A shelf life of more than 1 year satisfies the highest standard (Catroux et al. 2001). Such inoculants are now available in Europe and North and South America.

The following topics should be the top priorities of research on new or improved delivery systems for PGPB and rhizobia.

- In-depth evaluation of known carriers. Periodically, a new formulation involving a known carrier, such as alginate or liquid inoculant containing an adhesive, is presented as a solution to all the maladies of previous carriers. Yet, in-depth analysis of the pros and cons for each formulation are seldom investigated. Because dozens of carrier materials were proposed in recent decades of inoculation practices, fair and honest evaluation of the most common formulations, liquid, organic wastes, polymeric, deserves attention, excluding peat formulations that have already reached their pinnacle.

- Improvement of formulations that showed positive field results by fine-tuning key ingredients in the formulation (quantities, conditions, ratio of mixtures) or improvements in the process involved in their production. Although evaluation is assumed to be done by the industry, specific information is not available.

- Improve survival of the microorganism in the inoculant. Reducing the decline of the population of the inoculated bacteria during formulation and application should be a major target of research. If the death rate can be significantly reduced, it may be possible to raise the number of cells applied per seed by 2 or 3 orders of magnitude. These involved the parameters of physiological age of cells (phase of growth) and relative humidity and water activity $\left(\mathrm{a}_{\mathrm{w}}\right)$ during storage, which is species-dependent. The lower the $a_{w}$, the better is survival. This is because $a_{w}$ is a prime factor in survival, especially under high temperatures. Also, optimize the rate of rehydration. Slow-drying is usually superior to fastdrying (Date 2001).

- Shelf life. This is an essential commercial issue because application time in the field is short, while production time in the factory of large quantities is long and usually cannot be done close to application time. Current shelf life is relatively short. Two years is considered optimal. Yet, various experimental formulations, such those involving alginate, show that survival of the microorganism, without loosing efficacy for several years, can be achieved. This avenue deserves better attention, even though it takes years to obtain the data.

- Multi-strain inoculants and combination of inoculants containing rhizobia and a PGPB or biocontrol agent. Numerous studies have shown the advantages of these combinations, usually done in the laboratory without any formulation. While formulation of several microorganisms does not add additional significant technical difficulties compared to formulation of one microorganism, the interaction of the partners within these formulations are largely unknown. Development of such inoculants require explorations regarding 1) compatibility between microbial populations, 2) symbiosis or interaction with plants, 3) efficiency of their resulting plant growthpromoting effects, 4) their growth rate when together, 5) potential biofilm formation and, 6) technical difficulties of culturing microorganisms in fermenter, where each has different nutritional requirements or other in vitro growth conditions (Reddy and Saravanan 2013). As multi-strain applications appear to be the current frontier in this field, appropriate formulation should address these combinations.

- Supplementation with additives to many formulations is a given, as shown in Table s1. However, studies of additives used in formulations have been done ad hoc and are largely empirical. Seldom is their mode of action understood. This part of the 
formulation process is a virgin field and deserves more attention.

- Polymeric inoculants. Even though many indications pointed out that this is perhaps the future of inoculants, no formulation of PGPB or rhizobia has passed the threshold of industrial approval, as happened in other industries. Bio-encapsulation is a large emerging field in pharmaceutical, nanotechnology, medicine, aquaculture, and cosmetics. Many different and efficient encapsulation techniques were developed for that purposes (Schoebitz et al. 2013). Almost none were evaluated in the inoculant field apart from direct polymerization of a few polymers. Many of these emerging technologies from other fields merit evaluation in the agricultural inoculant industry.

- It is highly unlikely that farming practices will significantly change, even to accommodate a technology that delivers a high-quality inoculant. Consequently, the goal should be to create formulations that are more than farmer-friendly, as some of the contemporary inoculants are. The best approach will be those formulations without additional farmer involvement in application, apart from purchasing "improved seeds" containing the desired microbes.

- Costs. Agriculture cannot sustain inoculants with high production costs or expensive carrier materials. Consequently, because of the large quantities of inoculants involved and main crops that employ inoculant are staple food crops (mainly cereals and legumes) and not cash crops, any technology must be developed with constantly lower costs in mind. It is unlikely that an outstanding formulation with elevated price will find a niche in this market.

- Low-cost technologies for extending the shelf life of inoculants at the farm level in developing countries need further development. For example, clay pots covered with wet jute bags give better shelf life for inoculants in India (Bhattacharya and Mishra 1994). Similar, low-cost technologies need to be developed for better performance of inoculants.

- Local strains should be used for improved performance because no PGPB strain will perform best in all farming conditions. Since the effectiveness of inoculation depends on multiple parameters, including the target plant species and soil and weather conditions, inoculants should also be differentiated and matched appropriately. This requirement complicates the task of providing effective inoculants because commercial incentives dictate keeping the variety of products small. This industrial requirement is contrary to the reality of diversity among crop species, inoculants species, and soil biotic communities that otherwise support the production and distribution of multiple inoculants. Local production and distribution of selected native PGPB-rhizobia isolates might solve some of the current issues plaguing the field performance of inoculants (Selvamukilan et al. 2006).

- Create specific formulations for use under suboptimal farming conditions. Those include saline soils, drought, high temperatures, acid soils, marginal eroded soils, or soils with limited access for maintenance of plant cultivation,. For such problems, local PGPB-rhizobia strains that are tolerant or resistant to the physical or chemical stressor can be used, such as salt tolerant strains (Balasubramanian and Prabhu 1995).

- For transplanted crops, nursery inoculation is easier and usually provides better results. The cost of product and application will be far smaller, compared to field treatment. This is because the volume of the inoculated substrate is small and growth conditions are easier to control. Consequently, more research and transfer of technologies to farmers should be targeted to nursery-grown plants. For example, seedling roots dipped in microbial inoculants is effective and easy for microbial inoculation of transplanted crops such as rice (Choudhury and Kennedy 2004). This treatment needs to be finetuned for other transplanted crops.

- Inoculants made of active fragments of PGPB in the absence of living cells. Many elicitors of plant defenses and secondary metabolites of PGPB are well documented. These microbial products, if produced commercially, have potential as "inoculants" for reducing agrochemical use (Compant et al. 2012). For example, lipochito-oligosaccharides (LCOs) nod factors (Marks et al. 2013) secreted by rhizobia play a key role in the induction of nodules on the roots of legumes (Truchet et al. 1991). LCOs play a general role as growth regulators in a wide variety of plants, including non-legumes (Prithiviraj et al. 2003). Potential commercial LCO products for seed and foliar applications in legumes and nonlegumes, such as corn, are currently available in the marketplace in North America. More exploration in this direction is required to get more benefits from PGPB. 
- Publications in formal literature involving evaluation of proprietary formulations are largely unhelpful, apart for the extra public exposure for the manufacturer. The field experience of the farmer and market forces will determine whether such formulations are worth re-purchasing in the following growing season. Such publications contribute only ambiguity to this field.

Formulation and field application of inoculants are a pure technological platform with knowledge that is heavily based on fundamental principles of microbiology and material sciences. Yet, the unification of these fields creates useful products that are, and will be, an important input in sustainable agriculture and environmental solutions.

Acknowledgments We thank Ira Fogel of CIBNOR for editorial and English improvements. We thank several anonymous industrial scientists for providing information, and Prof. Hani Antoun, Laval University, Quebec, Canada and Prof Ivan Kennedy, University of Sydney, Sydney, Australia for consultation during the review process. This review was supported by The Bashan Foundation, USA and by Consejo Nacional de Ciencia y Tecnología of Mexico (CONACYT-Basic Science-2009, contracts 130656 and 164548).

\section{References}

Adesemoye AO, Kloepper JW (2009) Plant-microbes interactions in enhanced fertilizer-use efficiency. Appl Microbiol Biotechnol 85:1-12

Afzal M, Yousaf S, Reichenauer TG, Sessitsch A (2012) The inoculation method affects colonization and performance of bacterial inoculant strains in the phytoremediation of soil contaminated with diesel oil. Int J Phytoremediat 14:35-47

Ahangar MA, Dar GH, Bhat ZA (2012) Growth response and nutrient uptake of blue pine (Pinus wallichiana) seedlings inoculated with rhizosphere microorganisms under temperate nursery conditions of Kashmir. Ann Forest Res 55:217-227

Albareda M, Rodriguez-Navarro DN, Camacho M, Temprano FJ (2008) Alternatives to peat as a carrier for rhizobia inoculant: solid and liquid formulations. Soil Biol Biochem 40:27712779

Albareda M, Rodriguez-Navarro DN, Temprano FJ (2009) Use of Sinorhizobium (Ensifer) fredii for soybean inoculants in south Spain. Eur J Agron 30:205-211

Alström S (2001) Characteristics of bacteria from oilseed rape in relation to their biocontrol activity against Verticillium dahliae. J Phytopathol 149:57-64

Amein T, Weber Z (2002) Seed treatment with strains of Pseudomonas fluorescens as potential biocontrol agents of wheat take-all. Z Pfanzenkrankheiten Pflanzenschutz 109: 655-661
Amer GA, Utkhede RS (2000) Developments of formulations of biological agents for management of root rot of lettuce and cucumber. Can J Microbiol 46:809-816

Amiet-Charpentier C, Gadille P, Digat B, Benoit JP (1998) Microencapsulation of rhizobacteria by spray-drying: formulation and survival studies. J Microencapsul 15:639-659

Anandham R, Sridar R, Nalayini P, Poonguzhali S, Madhaiyan M, Sa T (2007) Potential for plant growth promotion in groundnut (Arachis hypogaea L.) cv. ALR-2 by coinoculation of sulfur-oxidizing bacteria and Rhizobium. Microbiol Res 162: 139-153

Andrews M, James EK, Cummings SP, Zavalin AA, Vinogradova LV, McKenzie BA (2003) Use of nitrogen fixing bacteria inoculants as a substitute for nitrogen fertilizer for dryland Graminaceous crops: progress made, mechanisms of action and future potential. Symbiosis 35:209-229

Anith KN, Momol MT, Kloepper JW, Marois JJ, Olson SM, Jones JB (2004) Efficacy of plant growth-promoting rhizobacteria, acibenzolar-S-methyl, and soil amendment for integrated management of bacterial wilt of tomato. Plant Dis 88:669-673

Arora NK, Khare E, Naraian R, Maheshwar DK (2008) Sawdust as a superior carrier for production of multipurpose bioinoculant using plant growth promoting rhizobial and pseudomonad strains and their impact on productivity of Trifolium repense. Curr Sci 95:90-94

Atieno M, Herrmann L, Okalebo R, Lesueur D (2012) Efficiency of different formulations of Bradyrhizobium japonicum and effect of co-inoculation of Bacillus subtilis with two different strains of Bradyrhizobium japonicum. World J Microbiol Biotechnol 28:2541-2550

Bacilio M, Vazquez P, Bashan Y (2003) Alleviation of noxious effects of cattle ranch composts on wheat seed germination by inoculation with Azospirillum spp. Biol Fertil Soils 38:261-266

Bacilio M, Rodriguez H, Moreno M, Hernandez J-P, Bashan Y (2004) Mitigation of salt stress in wheat seedlings by a $g f p$ tagged Azospirillum lipoferum. Biol Fertil Soils 40:188-193

Balasubramanian A, Prabhu SR (1995) Plasmid control of osmotolerance in Azospirillum halopraeferans. J Microb Biotechnol 10:1-7

Bashan Y (1986a) Alginate beads as synthetic inoculant carriers for the slow release of bacteria that affect plant growth. Appl Environ Microbiol 51:1089-1098

Bashan Y (1986b) Significance of timing and level of inoculation with rhizosphere bacteria on wheat plants. Soil Biol Biochem 18:297-301

Bashan Y (1998) Inoculants of plant growth-promoting bacteria for use in agriculture. Biotechnol Adv 16:729-770

Bashan Y, Bustillos JJ, Leyva LA, Hernandez JP, Bacilio M (2006) Increase in auxiliary photoprotective photosynthetic pigments in wheat seedlings induced by Azospirillum brasilense. Biol Fertil Soils 42:279-285

Bashan Y, de-Bashan LE (2010) How the plant growth-promoting bacterium Azospirillum promotes plant growth - a critical assessment. Adv Agron 108:77-136

Bashan Y, Gonzalez LE (1999) Long-term survival of the plantgrowth-promoting bacteria Azospirillum brasilense and Pseudomonas fluorescens in dry alginate inoculant. Appl Microbiol Biotechnol 51:262-266

Bashan Y, Hernandez JP, Leyva LA, Bacilio M (2002) Alginate microbeads as inoculant carrier for plant growth-promoting bacteria. Biol Fertil Soils 35:359-368 
Bashan Y, Holguin G, de-Bashan LE (2004) Azospirillum-plant relationships: physiological, molecular, agricultural, and environmental advances (1997-2003). Can J Microbiol 50: 521-577

Bashan Y, Holguin G, Lifshitz R (1993) Isolation and characterization of plant growth-promoting rhizobacteria. In: Glick BR, Thompson JE (eds) Methods in plant molecular biology and biotechnology. CRC Press, Boca Raton, pp 331-345

Bashan Y, Levanony H (1987) Horizontal and vertical movement of Azospirillum brasilense $\mathrm{Cd}$ in the soil and along the rhizosphere of wheat and weeds in controlled and field environments. J Gen Microbiol 133:3473-3480

Bashan Y, Salazar B, Moreno M, Lopez BR, Linderman RG (2012) Reforestation of eroded desert soil with native trees: effects of inoculation with plant growth-promoting microorganisms, limited amounts of compost and water and plant density. J Environ Manag 102:26-36

Bashan Y, Salazar B, Puente ME (2009a) Responses of native legume desert trees used for reforestation in the Sonoran Desert to plant growth-promoting microorganisms in screen house. Biol Fertil Soils 45:655-662

Bashan Y, Salazar B, Puente ME, Bacilio M, Linderman RG (2009b) Enhanced establishment and growth of giant cardon cactus in an eroded field in the Sonoran Desert using native legume trees as nurse plants aided by plant growth-promoting microorganisms and compost. Biol Fertil Soils 45:585-594

Bashan Y, Trejo A, de-Bashan LE (2011) Development of two culture media for mass cultivation of Azospirillum spp. and for production of inoculants to enhance plant growth. Biol Fertil Soils 47:963-969

Ben Rebah F, Tyagi RD, Prevost D (2002a) Wastewater sludge as a substrate for growth and carrier for rhizobia: the effect of storage conditions on survival of Sinorhizobium meliloti. Bioresour Technol 83:145-151

Ben Rebah F, Tyagi RD, Prevost D, Surampalli RY (2002b) Wastewater sludge as a new medium for rhizobial growth. Water Qual Res J Can 37:353-370

Ben Rebah F, Prevost D, Yezza A, Tyagi RD (2007) Agroindustrial waste material and wastewater sludge for rhizobial inoculant production: a review. Bioresour Technol 98:35353546

Berg G (2009) Plant-microbe interactions promoting plant growth and health: perspectives for controlled use of microorganisms in agriculture. Appl Microbiol Biotechnol 84:11-18

Bextine BR, Thorvilson HG (2002) Field applications of baitformulated Beauveria bassiana alginate pellets for biological control of the red imported fire ant (Hymenoptera: Formicidae). Environ Entomol 31:746-752

Bharathi R, Vivekananthan R, Harish S, Ramanathan A, Samiyappan R (2004) Rhizobacteria based bioformulations for the management of fruit rot infection in chillies. Crop Prot 23:835-843

Bhattacharya P, Mishra UC (1994) A book on biofertilizer for extension workers. National Biofertilizer Development Centre, Department of Agriculture \& Cooperation, Government of India, Ghaziabad, $189 \mathrm{pp}$

Boruah HPD, Kumar BSD (2002) Plant disease suppression and growth promotion by a fluorescent Pseudomonas strain. Folia Microbiol 47:137-143

Brockwell J (1977) Application of legume seed inoculants. In: Hardy RWF, Gibson AH (eds) A treatise on dinitrogen fixation. Section 4. Agronomy and ecology. Wiley, New York, pp 277-309

Cakmakci R, Dönmez F, Aydın A, Sahin F (2006) Growth promotion of plants by plant growth-promoting rhizobacteria under greenhouse and two different field soil conditions. Soil Biol Biochem 38:1482-1487

Cakmakci R, Kantar F, Sahin F (2001) Effect of $\mathrm{N}_{2}$-fixing bacterial inoculation on yield of sugar beet and barley. J Plant Nutr Soil Sc 164:527-531

Carrillo-Garcia A, Bashan Y, Diaz Rivera E, Bethlenfalvay GJ (2000) Effects of resource island soils, competition, and inoculation with Azospirillum on survival and growth of Pachycereus pringlei, the giant cactus of the Sonoran Desert. Res Ecol 8:65-73

Catroux G, Hartmann A, Revellin C (2001) Trends in rhizobial inoculant production and use. Plant Soil 230:21-30

Chang SJ, Lee CH, Hsu CY, Wang YJ (2002) Biocompatible microcapsules with enhanced mechanical strength. J Biomed Mater Res 59:118-126

Choudhury ATMA, Kennedy IR (2004) Prospects and potentials for systems of biological nitrogen fixation in sustainable rice production. Biol Fertil Soils 39:219-227

Clayton GW, Rice WA, Lupwayi NZ, Johnston AM, Lafond GR, Grant CA, Walley F (2004a) Inoculant formulation and fertilizer nitrogen effects on field pea: nodulation, $\mathrm{N}_{2}$ fixation and nitrogen partitioning. Can J Plant Sci 84:79-88

Clayton GW, Rice WA, Lupwayi NZ, Johnston AM, Lafond GP, Grant CA, Walley F (2004b) Inoculant formulation and fertilizer nitrogen effects on field pea: crop yield and seed quality. Can J Plant Sci 84:89-96

Compant S, Brader G, Muzammil S, Sessitsch A, Lebrihi A, Mathieu F (2012) Use of beneficial bacteria and their secondary metabolites to control grapevine pathogen diseases. BioControl. doi:10.1007/s10526-012-9479-6

Cong PT, Dung TD, Hien TM, Hien NT, Choudhury ATMA, Kecskés KL, Kennedy IR (2009) Inoculant plant growthpromoting microorganisms enhance utilisation of urea-N and grain yield of paddy rice in southern Vietnam. Eur $\mathrm{J}$ Soil Biol 45:52-61

Covarrubias SA, de-Bashan LE, Moreno M, Bashan Y (2012) Alginate beads provide a beneficial physical barrier against native microorganisms in wastewater treated with immobilized bacteria and microalgae. Appl Microbiol Biotechnol 93:2669-2680

Cruz I, Bashan Y, Hernandez-Carmona G, de-Bashan LE (2013) Partial biological deterioration of alginate beads containing immobilized microalgae and bacteria during tertiary wastewater treatment. Appl Microbiol Biotechnol 97:9847-9858

Dal Bello GM, Mónaco CI, Simón MR (2002) Biological control of seedling blight of wheat caused by Fusarium graminearum with beneficial rhizosphere microorganisms. World J Microb Biotech 18:627-636

da Silva MF, de Souza AC, de Oliveira PJ, Xavier GR, Rumjanek NG, de Barros Soares LH, Reis VM (2012) Survival of endophytic bacteria in polymer-based inoculants and efficiency of their application to sugarcane. Plant Soil 356: 231-243

Date RA (2001) Advances in inoculant technology: a brief review. Aust J Exp Agr 41:321-325

Deaker R, Kecskés ML, Rose MT, Amprayn K, Ganisan K, Tran TKC, Vu TN, Phan TC, Hien NT, Kennedy IR (2011) 
Practical methods for the quality control of inoculant biofertilisers. ACIAR Monograph Series No.147, Canberra, p 101

Deaker R, Roughley RJ, Kennedy IR (2004) Legume seed inoculation technology - a review. Soil Biol Biochem 36:1275-1288

de-Bashan LE, Antoun H, Bashan Y (2005) Cultivation factors and population size control uptake of nitrogen by the microalgae Chlorella vulgaris when interacting with the microalgae growth-promoting bacterium Azospirillum brasilense. FEMS Microbiol Ecol 54:197-203

de-Bashan LE, Antoun H, Bashan Y (2008a) Involvement of indole-3-acetic-acid produced by the growth-promoting bacterium Azospirillum spp. in promoting growth of Chlorella vulgaris. J Phycol 44:938-947

de-Bashan LE, Bashan Y (2004) Recent advances in removing phosphorus from wastewater and its future use as fertilizer (1997-2003). Water Res 38:4222-4246

de-Bashan LE, Bashan Y (2008) Joint immobilization of plant growth-promoting bacteria and green microalgae in alginate beads as an experimental model for studying plant-bacterium interactions. Appl Environ Microbiol 74:6797-6802

de-Bashan LE, Bashan Y (2010) Immobilized microalgae for removing pollutants: review of practical aspects. Bioresour Technol 101:1611-1627

de-Bashan LE, Bashan Y, Moreno M, Lebsky VK, Bustillos JJ (2002a) Increased pigment and lipid content, lipid variety, and cell and population size of the microalgae Chlorella spp. when co-immobilized in alginate beads with the microalgaegrowth-promoting bacterium Azospirillum brasilense. Can J Microbiol 48:514-521

de-Bashan LE, Hernandez JP, Morey T, Bashan Y (2004) Microalgae growth-promoting bacteria as "helpers" for microalgae: a novel approach for removing ammonium and phosphorus from municipal wastewater. Water Res 38:466474

de-Bashan LE, Magallon P, Antoun H, Bashan Y (2008b) Role of glutamate dehydrogenase and glutamine synthetase in Chlorella vulgaris during assimilation of ammonium when jointly immobilized with the microalgae-growth-promoting bacterium Azospirillum brasilense. J Phycol 44:1188-1196

de-Bashan LE, Moreno M, Hernandez JP, Bashan Y (2002b) Removal of ammonium and phosphorus ions from synthetic wastewater by the microalgae Chlorella vulgaris coimmobilized in alginate beads with the microalgae growth-promoting bacterium Azospirillum brasilense. Water Res 36:2941-2948

de-Bashan LE, Trejo A, Huss VAR, Hernandez JP, Bashan Y (2008c) Chlorella sorokiniana UTEX 2805, a heat and intense, sunlight-tolerant microalga with potential for removing ammonium from wastewater. Bioresour Technol 99:4980-4989

Denton MD, Pearce DJ, Ballard RA, Hannah MC, Mutch LA, Norng S, Slattery JF (2009) A multi-site field evaluation of granular inoculants for legume nodulation. Soil Biol Biochem 41:2508-2516

Diaz-Zorita M, Fernandez-Canigia MV (2009) Field performance of a liquid formulation of Azospirillum brasilense on dryland wheat productivity. Eur J Soil Biol 45:3-11

Diouf D, Forestier S, Neyra M, Lesueur D (2003) Optimisation of inoculation of Leucaena leucocephala and Acacia mangium with rhizobium under greenhouse conditions. Ann For Sci 60:379-384
Dominguez-Nuñez JA, Muñoz D, Planelles R, Grau JM, Artero F, Anriquez A, Albanesi A (2012) Inoculation with Azospirillum brasilense enhances the quality of mesquite Prosopis juliflora seedlings. For Syst 21:364-372

Draget KI, Smidsrød O, Skjåk-Bræk G (2002) Alginates from algae. In: Steinbüchel A, De Daets S, Vandame EJ (eds) Biopolymers. vol. 6: Polysacharides II. Wiley-VCH, Weinheim, pp 215-240

Egamberdiyeva D (2007) The effect of plant growth promoting bacteria on growth and nutrient uptake of maize in two different soils. Appl Soil Ecol 36:184-189

Eiselt P, Yeh J, Latvala RK, Shea LD, Mooney DJ (2000) Porous carriers for biomedical applications based on alginate hydrogels. Biomaterials 21:1921-1927

El-Komy HMA (2005) Coimmobilization of Azospirillum lipoferum and Bacillus megaterium for successful phosphorus and nitrogen nutrition of wheat plants. Food Technol Biotech 43:19-27

El-Tarabily KA (2004) Suppression of Rhizoctonia solani diseases of sugar beet by antagonistic and plant growth-promoting yeasts. J Appl Microbiol 96:69-75

El-Tarabily KA, Soliman MH, Nassar AH, Al-Hassani HA, Sivasithamparam K, McKenna F, Hardy GESJ (2000) Biological control of Sclerotinia minor using a chitinolytic bacterium and actinomycetes. Plant Pathol 49:573-583

Esitken A, Karlidag H, Ercisli S, Turan M, Sahin F (2003) The effect of spraying a growth promoting bacterium on the yield, growth and nutrient element composition of leaves of apricot (Prunus armeniaca L. cv. Hacihaliloglu). Aust J Agr Res 54: 377-380

Forestier S, Alvarado G, Badjel SB, Lesueur D (2001) Effect of Rhizobium inoculation methodologies on nodulation and growth of Leucaena leucocephala. 2001. World J Microbiol Biotechnol 17:359-362

Friel LT, McLoughlin AJ (1999) Immobilisation as a strategy to increase the ecological competence of liquid cultures of Agaricus bisporus in pasteurised compost. FEMS Microbiol Ecol 30:39-46

Fuentes-Ramirez LE, Caballero-Mellado J (2005) Bacterial biofertilizers. In: Siddiqui ZA (ed) PGPR: Biocontrol and biofertilization. Springer, Dordrecht, pp 143-172

Fürnkranz M, Adam E, Müller H, Grube M, Huss H, Winkler J, Berg G (2012) Promotion of growth, health and stress tolerance of Styrian oil pumpkins by bacterial endophytes. Eur J Plant Pathol 134:509-519

Gamal-Eldin H, Elbanna K (2011) Field evidence for the potential of Rhodobacter capsulatus as biofertilizer for flooded rice. Curr Microbiol 62:391-395

Garcia OA, Sarmiento M (2000) A note on the viability of Azospirillum brasilense in turf used as carrier in inoculated grass seeds. Cuban J Agr Sci 34:343-345

Gaumann A, Laudes M, Jacob B, Pommersheim R, Laue C, Vogt W, Schrezenmeir J (2000) Effect of media composition on long-term in vitro stability of barium alginate and polyacrylic acid multilayer microcapsules. Biomaterials 21:1911-1917

Gonzalez LE, Bashan Y (2000) Increased growth of the microalga Chlorella vulgaris when coimmobilized and cocultured in alginate beads with the plant growth-promoting bacterium Azospirillum brasilense. Appl Environ Microbiol 66:1527-1531

Gonzalez-Bashan LE, Lebsky V, Hernandez JP, Bustillos JJ, Bashan Y (2000) Changes in the metabolism of the 
microalgae Chlorella vulgaris when coimmobilized in alginate with the nitrogen-fixing Phyllobacterium myrsinacearum. Can J Microbiol 46:653-659

Guetsky R, Elad Y, Shtienberg D, Dinoor A (2002a) Improved biocontrol of Botrytis cinerea detached strawberry leaves by adding nutritional supplements to a mixture of Pichia guilermondii and Bacillus mycoides. Biocontrol Sci Techn 12:625-630

Guetsky R, Elad Y, Shtienberg D, Dinoor A (2002b) Establishment, survival and activity of the biocontrol agents Pichia guilermondii and Bacillus mycoides applied as a mixture on strawberry plants. Biocontrol Sci Techn 12:705-714

Guiñazú LB, Andrés JA, Del Papa MF, Pistorio M, Rosas SB (2010) Response of alfalfa (Medicago sativa L.) to single and mixed inoculation with phosphate-solubilizing bacteria and Sinorhizobium meliloti. Biol Fertil Soils 46:185-190

Gurley HG, Zdor RE (2005) Differential rhizosphere establishment and cyanide production by alginate-formulated weeddeleterious rhizobacteria. Curr Microbiol 50:167-171

Hamaoui B, Abbadi JM, Burdman S, Rashid A, Sarig S, Okon Y (2001) Effects of inoculation with Azospirillum brasilense on chickpeas (Cicer arietinum) and faba beans (Vicia faba) under different growth conditions. Agronomie 21:553-560

Hartmann A, Bashan Y (2009) Ecology and application of Azospirillum and other plant growth-promoting bacteria (PGPB) - special issue. Eur J Soil Biol 45:1-2

Hashem MA (2001) Problems and prospects of cyanobacterial biofertilizer for rice cultivation. Aust J Plant Physiol 28:881-888

Hernandez JP, de-Bashan LE, Bashan Y (2006) Starvation enhances phosphorus removal from wastewater by the microalga Chlorella spp. co-immobilized with Azospirillum brasilense. Enzyme Microb Tech 38:190-198

Hernandez JP, de-Bashan LE, Rodriguez DJ, Rodriguez Y, Bashan Y (2009) Growth promotion of the freshwater microalga Chlorella vulgaris by the nitrogen-fixing, plant growthpromoting bacterium Bacillus pumilus from arid zone soils. Eur J Soil Biol 45:88-93

Herridge DF (2007) Inoculation technology for legumes. In: Dilworth MJ, James EK, Sprent JI, Newton WE (eds) Nitrogen-fixing leguminous symbioses., vol 7, Springer. Dordrecht, The Netherlands, pp 77-115

Hossain MS, Mårtensson A (2008) Potential use of Rhizobium spp. to improve fitness of non-nitrogen-fixing plants. Acta Agr Scand B S P 58:352-358

Hungria M, Campo RJ, Souza EM, Pedrosa FO (2010) Inoculation with selected strains of Azospirillum brasilense and $A$. lipoferum improves yields of maize and wheat in Brazil. Plant Soil 331:413-425

Hynes RK, Jans DC, Bremer E, Lupwayi NZ, Rice WA, Clayton GW, Collins MM (2001) Rhizobium population dynamics in the pea rhizosphere of rhizobial inoculant strain applied in different formulations. Can J Microbiol 47:595-600

Jetiyanon K, Fowler W, Kloepper JW (2003) Broad-spectrum protection against several pathogens by PGPR mixtures under field conditions in Thailand. Plant Dis 87:1390-1394

Jha CK, Saraf M (2012) Evaluation of multispecies plant-growthpromoting consortia for the growth promotion of Jatropha curcas L. J Plant Growth Regul 31:588-598

John RP, Tyagi RD, Brar SK, Surampalli RY, Prevost D (2011) Bio-encapsulation of microbial cells for targeted agricultural delivery. Crit Rev Biotechnol 31:211-226
Johri BN, Sharma A, Virdi JS (2003) Rhizobacterial diversity in India and its influence on soil and plant health. Adv Biochem Eng Biotechnol 84:49-89

Jones LR, Owen SA, Horrell P, Burns RG (1998) Bacterial inoculation of granular activated carbon filters for the removal of atrazine from surface water. Water Res 32:2542-2549

Júnior PIF, Rohr TG, de Oliveira PJ, Xavier GR, Rumjanek NG (2009) Polymers as carriers for rhizobial inoculant formulations. Pesq Agropec Bras 44:1184-1190

Khan A, Sutton JC, Grodzinski B (2003) Effect of Pseudomonas chlororaphis on Pythium aphanidermatum and root rot in peppers grown in small-scale hydoponic troughs. Biocontrol Sci Techn 13:615-630

Khalid A, Arshad M, Zahir ZA (2004) Screening plant growthpromoting rhizobacteria for improving growth and yield of wheat. J Appl Microbiol 96:473-480

Kokalis-Burelle N, Vavrina CS, Reddy MS, Kloepper JW (2003) Amendment of muskmelon and watermelon transplant media with plant growth-promoting rhizobacteria: effect on seedling quality, disease and nematode resistance. HortTechnology 13:476-482

Kong HJ, Mooney DJ (2003) The effects of poly(ethyleneimine) (PEI) molecular weight on reinforcement of alginate hydrogels. Cell Transplant 12:779-785

Kostov O, Lynch JM (1998) Composted sawdust as a carrier for Bradyrhizobium, Rhizobium and Azospirillum in crop inoculation. World J Microb Biot 14:389-397

Kurek E, Jaroszuk-Ściseł J (2002) Rye (Secale cereale) growth promotion by Pseudomonas fluorescens strains and their interactions with Fusarium culmorum under various soil conditions. Biol Control 26:48-56

Landa BB, Navas-Cortés JA, Hervás A, Jiménez-Díaz RM (2001) Influence of temperature and inoculum density of Fusarium oxysporum f. sp. ciceris on suppression of Fusarium wilt of chickpea by rhizosphere bacteria. Phytopathology 91:807-816

Lebsky VK, Gonzalez-Bashan LE, Bashan Y (2001) Ultrastructure of interaction in alginate beads between the microalga Chlorella vulgaris with its natural associative bacterium Phyllobacterium myrsinacearum and with the plant growth-promoting bacterium Azospirillum brasilense. Can J Microbiol 47:1-8

Li J, Zhang S, Shi S, Huo P (2011) Four materials as carriers for phosphate dissolving Rhizobium sp. inoculants. Adv Mater Res 156-157:919-928

Lodewyckx C, Vangronsveld J, Porteous F, Moore ERB, Taghavi S, Mezgeay M, van der Lelie D (2002) Endophytic bacteria and their potential applications. Crit Rev Plant Sci 21:583606

Lopez BR, Bashan Y, Trejo A, de-Bashan LE (2013) Amendment of degraded desert soil with wastewater debris containing immobilized Chlorella sorokiniana and Azospirillum brasilense significantly modifies soil bacterial community structure, diversity, and richness. Biol Fertil Soils 49:10531063

Lucy M, Reed E, Glick BR (2004) Applications of free living plant growth-promoting rhizobacteria. Van Leeuw 86:1-25

Mäder P, Kaiser F, Adholeya A, Singh R, Uppal HS, Sharma AK, Srivastava R, Sahai V, Aragno M, Wiemken A, Johri BN, Fried PM (2011) Inoculation of root microorganisms for sustainable wheat-rice and wheat-black gram rotations in India. Soil Biol Biochem 43:609-619 
Madhaiyan M, Poonguzhali S, Kang B-G, Lee Y-J, Chung J-B, Sa T-M (2010) Effect of co-inoculation of methylotrophic Methylobacterium oryzae with Azospirillum brasilense and Burkholderia pyrrocinia on the growth and nutrient uptake of tomato, red pepper and rice. Plant Soil 328:71-82

Malliga P, Uma L, Subramanian G (1996) Lignolytic activity of the cyanobacterium Anabena azollae ML2 and the value of coir waste as a carrier for biofertilizer. Microbios 86:175-183

Manikandan R, Saravanakumar D, Rajendran L, Raguchander T, Samiyappan R (2010) Standardization of liquid formulation of Pseudomonas fluorescens Pf1 for its efficacy against Fusarium wilt of tomato. Biol Control 54:83-89

Manjula K, Podile AR (2001) Chitin-supplemented formulations improve bicontrol and plant growth promoting efficiency of Bacillus subtilis AF 1. Can J Microbiol 47:618-625

Marks BB, Megias M, Nogueira MA, Hungria M (2013) Biotechnological potential of rhizobial metabolites to enhance the performance of Bradyrhizobium spp. and Azospirillum brasilense inoculants with soybean and maize. AMB Expr 3:21

Mathre DE, Cook RJ, Callan NW (1999) From discovery to use. Traversing the world of commercializing biocontrol agents for plant disease control. Plant Dis 83:972-983

Mathu S, Herrmann L, Pypers P, Matiru V, Mwirichia R, Lesueur D (2012) Potential of indigenous bradyrhizobia versus commercial inoculants to improve cowpea (Vigna unguiculata L. walp.) and green gram (Vigna radiata L. wilczek.) yields in Kenya. Soil Sci Plant Nutr 58:750-763

Maurice S, Beauclair P, Giraud JJ, Sommer G, Hartmann A, Catroux G (2001) Survival and change in physiological state of Bradyrhizobium japonicum in soybean (Glycine max L. Merril) liquid inoculants after long-term storage. World J Microb Biot 17:635-643

Mehnaz S, Kowalik T, Reynolds B, Lazarovits G (2010) Growth promoting effects of corn (Zea mays) bacterial isolates under greenhouse and field conditions. Soil Biol Biochem 42: $1848-1856$

Meyer SLF, Massoud SI, Chitwood DJ, Roberts DP (2000) Evaluation of Trichoderma virens and Burkholderia cepacia for antagonistic activity against root-knot nematode, Meloidogyne incognita. Nematology 2:871-879

Meyer SLF, Roberts DP, Chitwood DJ, Carta LK, Lumsden RD, Mao W (2001) Application of Burkholderia cepacia and Trichoderma virens, alone and in combination, against Meloidogyne incognita on bell pepper. Nematropica 31:75-86

Moënne-Loccoz Y, Naughton M, Higgins P, Powell J, O’Connor B, O'Gara F (1999) Effect of inoculum preparation and formulation on survival and biocontrol efficacy of Pseudomonas fluorescens F113. J Appl Microbiol 86:108-116

Murakata T, Honma H, Nakazato S, Kuroda C, Sato S (2001) Control of particle size of calcium alginate gel bead by application of electric field to interface between aqueous and organic phases. J Chem Eng Jpn 34:299-305

Murphy JF, Reddy MS, Ryu C-M, Kloepper JW, Li R (2003) Rhizobacteria-mediated growth promotion of tomato leads to protection against Cucumber mosaic virus. Phytopathology 93:1301-1307

Nassar AH, El-Tarabily KA, Sivasithamparam K (2003) Growth promotion of bean (Phaseolus vulgaris L.) by a polyamineproducing isolate of Streptomyces griseoluteus. Plant Growth Regul 40:97-106
Nguyen HT, Deaker R, Kennedy IR, Roughley RJ (2003) The positive yield response of field-grown rice to inoculation with multi-strain biofertilizer in the Hanoi area, Vietnam. Symbiosis 35:231-245

Nussinovitch A (2010) Polymer macro- and micro-gel beads: fundamentals and applications. Springer, Berlin, $303 \mathrm{pp}$

Odee DW, Indieka SA, Lesueur D (2002) Evaluation of inoculation procedures for Calliandra calothyrsus Meisn. grown in tree nurseries. Biol Fertil Soils 36:124-128

Ozturk A, Caglar O, Sahin F (2003) Yield response of wheat and barley to inoculation of plant growth promoting rhizobacteria at various levels of nitrogen fertilization. J Plant Nutr Soil Sci 166:262-266

Perez-Garcia O, de-Bashan LE, Hernandez JP, Bashan Y (2010) Efficiency of growth and nutrient uptake from wastewater by heterotrophic, autotrophic, and mixotrophic cultivation of Chlorella vulgaris immobilized with Azospirillum brasilense. J Phycol 46:800-812

Piccinin GG, Braccini AL, Dan LGM, Scapim CA, Ricci TT, Bazo GL (2013) Efficiency of seed inoculation with Azospirillum brasilense on agronomic characteristics and yield of wheat. Ind Crop Prod 43:393-397

Plessner OE, Chen Y, Shenker M, Tel Or E (1998) Iron-enriched Azolla as a slow-release biofertilizer for cucumber plants grown in a hydroponic system. J Plant Nutr 21:2357-2367

Polyak B, Geresh S, Marks RS (2004) Synthesis and characterization of a biotin-alginate conjugate and its application in a biosensor construction. Macromolecules 5:389-396

Prabhu SR, Thomas GV (2002) Bioconversion of coir pith into value added organic resource and its application in agrihorticulture: current status, prospects and perspective. J Plant Crops 30:1-17

Prasad K, Kadokawa J-I (2009) Alginate-based blends and nano/ microbeads. Microbiol Monogr 13:175-210

Prithiviraj B, Zhou X, Souleimanov A, Khan WK, Smith DL (2003) A host specific bacteria-to-plant signal molecule (Nod factor) enhances germination and early growth of diverse crop plants. Planta 216:437-445

Puente ME, Li CY, Bashan Y (2004a) Microbial populations and activities in the rhizoplane of rock-weathering desert plants. II. Growth promotion of cactus seedlings. Plant Biol 6:643650

Puente ME, Li CY, Bashan Y (2009a) Rock-degrading endophytic bacteria in cacti. Environ Exp Bot 66:389-401

Puente ME, Li CY, Bashan Y (2009b) Endophytic bacteria in cacti seeds can improve the development of cactus seedlings. Environ Exp Bot 66:402-408

Puente ME, Bashan Y, Li CY, Lebsky VK (2004b) Microbial populations and activities in the rhizoplane of rockweathering desert plants. I. root colonization and weathering of igneous rocks. Plant Biol 6:29-642

Radjacommare R, Nandakumar R, Kandan A, Suresh S, Bharathi M, Raguchander T, Samiyappan R (2002) Pseudomonas fluorescens based bioformulation for the management of sheath blight and leaffolder in rice. Crop Prot 21:671-677

Rajapaksha RMCP, Herath D, Senanayake AP, Senevirathne MGTL (2011) Mobilization of rock phosphate phosphorus through bacterial inoculants to enhance growth and yield of wetland rice. Commun Soil Sci Plan 42:301-314

Raja Sekar K, Karmegam N (2010) Earthworm casts as an alternate carrier material for biofertilizers: assessment of 
endurance and viability of Azotobacter chroococcum, Bacillus megaterium and Rhizobium leguminosarum. Sci Hortic 124:286-289

Reddy CA, Saravanan RS (2013) Polymicrobial multi-functional approach for enhancement of crop productivity. Adv Appl Microbiol 82:53-113

Rekha PD, Lai WA, Arun AB, Young CC (2007) Effect of free and encapsulated Pseudomonas putida CC-FR2-4 and Bacillus subtilis CC-pg104 on plant growth under gnotobiotic conditions. Bioresour Technol 98:447-451

Revellin C, Meunier G, Giraud J-J, Sommer G, Wadoux P, Catroux G (2000) Changes in the physiological and agricultural characteristics of pest-based Bradyrhizobium japonicum inoculants after long-term storage. Appl Microbiol Biotechnol 54:206-211

Riggs PJ, Chelius MK, Iniguez AL, Kaeppler SM, Triplett EW (2001) Enhanced maize productivity by inoculation with diazotrophic bacteria. Aust J Plant Physiol 28:829-836

Rivera-Cruz MC, Trujillo Narcía A, Córdova Ballona G, Kohler J, Caravaca F, Roldán A (2008) Poultry manure and banana waste are effective biofertilizer carriers for promoting plant growth and soil sustainability in banana crops. Soil Biol Biochem 40:3092-3095

Rizvi PQ, Choudhury RA, Ali A (2009) Recent advances in biopesticides. In: Khan MS, Zaidi A, Musarrat J (eds) Microbial strategies for crop improvement. Springer Verlag, Berlin, pp 185-203

Russo A, Basaglia M, Tola E, Casella S (2001) Survival, root colonisation and biocontrol capacities of Pseudomonas fluorescens F113 LacZY in dry alginate microbeads. J Ind Microbiol Biotechnol 27:337-342

Sabaratnam S, Traquair JA (2002) Formulation of a Streptomyces biocontrol agent for the suppression of Rhizoctonia dampingoff in tomato transplants. Biol Control 23:245-253

Sabra W, Zeng AP, Deckwer WD (2001) Bacterial alginate: physiology, product quality and process aspects. Appl Microbiol Biotechnol 56:315-325

Saravanakumar D, Harish S, Loganathan M, Vivekananthan R, Rajendran L, Raguchander T, Samiyappan R (2007a) Rhizobacterial bioformulation for the effective management of Macrophomina root rot in mungbean. Archiv Phytopathol Plant Protect 40:323-337

Saravanakumar D, Lavanya N, Muthumeena K, Raguchander T, Samiyappan R (2009) Fluorescent pseudomonad mixtures mediate disease resistance in rice plants against sheath rot (Sarocladium oryzae) disease. Biocontrol 54:273-286

Saravanakumar D, Vijayakumar C, Kumar N, Samiyappan R (2007b) PGPR induced defense responses in tea plants against blister blight disease. Crop Prot 26:556-565

Sarrocco S, Raeta R, Vannacci G (2004) Seeds encapsulation in calcium alginate pellets. Seed Sci Technol 32: 649-661

Schoebitz M, López MD, Roldán A (2013) Bioencapsulation of microbial inoculants for better soil-plant fertilization. A review. Agron Sustain Dev. doi:10.1007/s13593-013-0142-0

Schoebitz M, Mengual C, Roldán A (2014) Combined effects of clay immobilized Azospirillum brasilense and Pantoea dispersa and organic olive residue on plant performance and soil properties in the re-vegetation of a semiarid area. Sci Total Environ 466-467:67-73
Schoebitz M, Simonin H, Poncelet D (2012) Starch filler and osmoprotectants improve the survival of rhizobacteria in dried alginate beads. J Microencapsul 29:532-538

Schulz TJ, Thelen KD (2008) Soybean seed inoculant and fungicidal seed treatment effects on soybean. Crop Sci 48:1975-1983

Selvamukilan B, Rengalakshmi S, Tamizoli P, Nair S (2006) Village-level production and use of biocontrol agents and biofertizers. In: Uphoff N, Ball AS, Fernades E, Herren H, Husson O, Laing M, Palm C, Pretty J, Sanchez P, Sanginga $\mathrm{N}$, Thies J (eds) Biological approaches to sustainable soil systems. CRC Press, Boca Raton, pp 647-653

Sigler WV, Nakatsu CH, Reicher ZJ, Turco RF (2001) Fate of the biological control agent Pseudomonas aureofaciens TX-1 after application to turfgrass. Appl Environ Microbiol 67: 3542-3548

Singh S, Rekha PD, Arun AB, Hameed A, Singh S, Shen FT, Young CC (2011) Glutamate wastewater as a culture medium for Azospirillum rugosum production and its impact on plant growth. Biol Fertil Soils 47:419-426

Singleton P, Keyser H, Sande E (2002) Development and evaluation of liquid inoculants, in: Herridge D (ed) Inoculants and nitrogen fixation of legumes in Vietnam. ACIAR Proceedings 109e, Canberra, pp 52-66

Stephens JHG, Rask HM (2000) Inoculant production and formulation. Field Crops Res 65:249-258

Sudhakar P, Chattopadhyay GN, Gangwar SK, Ghosh JK (2000) Effect of foliar application of Azotobacter, Azospirillum and Beijerinckia on leaf yield and quality of mulberry (Morus alba). J Agric Sci Camb 134:227-234

Taurian T, Anzuay MS, Angelini JG, Tonelli ML, Ludueña L, Pena D, Ibáñez F, Fabra A (2010) Phosphate-solubilizing peanut associated bacteria: screening for plant growthpromoting activities. Plant Soil 329:421-431

Temprano FJ, Albareda M, Camacho M, Daza A, Santamaría C, Rodríguez-Navarro DN (2002) Survival of several Rhizobium/Bradyrhizobium strains on different inoculant formulations and inoculated seeds. Int Microbiol 5:81-86

Tonnesen HH, Karlsen J (2002) Alginate in drug delivery systems. Drug Dev Ind Pharm 28:621-630

Trifonova R, Postma J, Schilder MT, van Elsas JD (2009) Microbial enrichment of a novel growing substrate and its effect on plant growth. Microb Ecol 58:632-641

Trejo A, de-Bashan LE, Hartmann A, Hernandez JP, Rothballer M, Schmid M, Bashan Y (2012) Recycling waste debris of immobilized microalgae and plant growth-promoting bacteria from wastewater treatment as a resource to improve fertility of eroded desert soil. Environ Exp Bot 75:65-73

Trivedi P, Pandey A (2008) Recovery of plant growth-promoting rhizobacteria from sodium alginate beads after 3 years following storage at 4 degrees. J Ind Microbiol Biotechnol 35: 205-209

Trivedi P, Pandey A, Palni LMS (2005) Carrier-based preparations of plant growth-promoting bacterial inoculants suitable for use in cooler regions. World J Microb Biot 21:941-945

Truchet G, Roche P, Lerouge P, Vasse J, Camut S, de Billy F, Prome J-C, Denarie J (1991) Sulphated lipo-oligosaccharide signals of Rhizobium meliloti elicit root nodule organogenesis in alfalfa. Nature 351:670-673

Trujillo-Roldán MA, Moreno S, Segura D, Galindo E, Espín G (2003) Alginate production by an Azotobacter vinelandii 
mutant unable to produce alginate lyase. Appl Microbiol Biotechnol 60:733-737

Tsagou V, Aggelis G (2008) Growth and nitrogen fixation of Azospirillum lipoferum cultivated on olive oil mill wastewater. In: Couto GN (ed) Nitrogen fixation research progress. Nova, New York, pp 355-366

Tuomi T, Heino M, Rosenqvist H, Nordstrom K, Laakso S (2001) Fiber fractions from processing of barley in production and conservation of a biologic control agent. Appl Biochem Biotech 94:135-145

Van Nieuwenhove C, Van Holm L, Kulasooriya SA, Vlassak K (2000) Establishment of Azorhizobium caulinodans in the rhizosphere of wetland rice (Oryza sativa L.). Biol Fertil Soils 31:143-149

Vassilev N, Vassileva M, Azcon R, Medina A (2001) Application of free and Ca-alginate-entrapped Glomus deserticola and Yarowia lipolytica in a soil-plant system. J Biotechnol 91:237-242

Vessey JK (2003) Plant growth promoting rhizobacteria as biofertilizers. Plant Soil 255:571-586

Viji G, Uddin W, Romaine CP (2003) Suppression of gray leaf spot (blast) of perennial ryegrass turf by Pseudomonas aeruginosa from spent mushroom substrate. Biol Control 26:233-243

Viswanathan R, Samiyappan R (2001) Role of chitinases in Pseudomonas spp. induced systemic resistance against Colletotrichum falcatum in sugarcane. Indian Phytopathol 54:418-423

Viveganandan G, Jauhri KS (2000) Growth and survival of phosphate-solubilizing bacteria in calcium alginate. Microbiol Res 155:205-207

Vivekananthan R, Ravi M, Ramanathan A, Samiyappan R (2004) Lytic enzymes induced by Pseudomonas fluorescens and other biocontrol organisms mediate defence against the anthracnose pathogen in mango. World J Microb Biot 20:235-244

Wang L, Khor E, Lim L-Y (2001) Chitosan-alginate- $\mathrm{CaCl}_{2}$ system for membrane coat application. J Pharm Sci 90:1134-1142
Wani PA, Khan MS, Zaidi A (2007) Effect of metal tolerant plant growth promoting Bradyrhizobium sp. (vigna) on growth, symbiosis, seed yield and metal uptake by greengram plants. Chemosphere 70:36-45

Xavier IJ, Holloway G, Leggett M (2004) Development of rhizobial inoculant formulations. Online Crop Manag Netw. doi: 10.1094/CM-2004-0301-06-RV

Young CC, Rekha P, Lai WA, Arun AB (2006) Encapsulation of plant growth-promoting bacteria in alginate beads enriched with humic acid. Biotechnol Bioeng 95:76-83

Yabur R, Bashan Y, Hernández-Carmona G (2007) Alginate from the macroalgae Sargassum sinicola as a novel source for microbial immobilization material in wastewater treatment and plant growth promotion. J Appl Phycol 19:43-53

Yan Z, Reddy MS, Kloepper JW (2003) Survival and colonization of rhizobacteria in a tomato transplant system. Can J Microbiol 49:383-389

Yu X, Liu X, Zhu TH, Liu GH, Mao C (2011) Isolation and characterization of phosphate-solubilizing bacteria from walnut and their effect on growth and phosphorus mobilization. Biol Fertil Soils 47:437-446

Zafar M, Abbasi MK, Khan MA, Khaliq A, Sultan T, Aslam M (2012) Effect of plant growth-promoting rhizobacteria on growth, nodulation and nutrient accumulation of lentil under controlled conditions. Pedosphere 22:848-859

Zhang XY, Zhao H, Zhang JN, Li ZH (2004) Growth of Azotobacter vinelandii in a solid-state fermentation of technical lignin. Bioresource Technol 95:31-33

Zohar-Perez C, Chernin L, Chet I, Nussinovitch A (2003) Structure of dried cellular alginate matrix containing fillers provides extra protection for microorganisms against UVC radiation. Radiat Res 160:198-204

Zohar-Perez C, Ritte E, Chernin L, Chet I, Nussinovitch A (2002) Preservation of chitinolytic Pantoae agglomerans in a viable form by cellular dried alginate-based carriers. Biotechnol Prog 18:1133-1140 